\title{
Hydrostratigraphic Mapping of the Milford-Souhegan Glacial Drift Aquifer, and Effects of Hydrostratigraphy on Transport of PCE, Operable Unit 1, Savage Superfund Site, Milford, New Hampshire
}

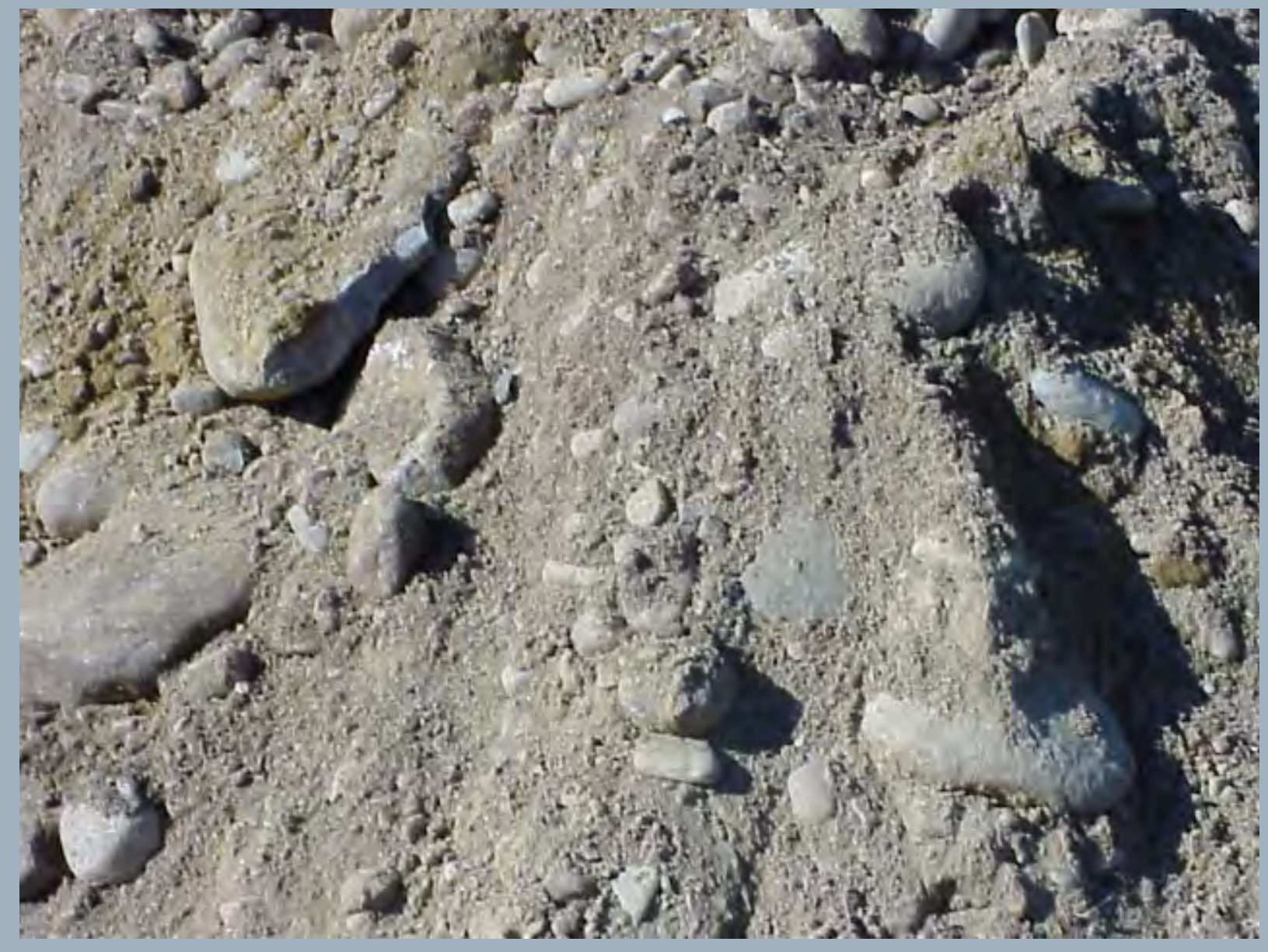

Open-File Report 2010-1047 
Cover. Photograph of sediments excavated from an upper cobble unit layer about 15 feet below land surface. The poorly sorted unit can contain fine sands to boulders, and its hydraulic conductivity is controlled by the amount of fine sands interspersed within a matrix between the cobbles and boulders. 


\section{Hydrostratigraphic Mapping of the Milford- Souhegan Glacial Drift Aquifer, and Effects of Hydrostratigraphy on Transport of PCE, Operable Unit 1, Savage Superfund Site, Milford, New Hampshire}

By Philip T. Harte

Prepared in cooperation with the

New Hampshire Department of Environmental Services and the

U.S. Environmental Protection Agency, Region 1

Open-File Report 2010-1047 


\section{U.S. Department of the Interior \\ KEN SALAZAR, Secretary \\ U.S. Geological Survey \\ Marcia K. McNutt, Director}

U.S. Geological Survey, Reston, Virginia: 2010

For more information on the USGS - the Federal source for science about the Earth, its natural and living resources, natural hazards, and the environment, visit http://www.usgs.gov or call 1-888-ASK-USGS

For an overview of USGS information products, including maps, imagery, and publications, visit http://www.usgs.gov/pubprod

To order this and other USGS information products, visit http://store.usgs.gov

Any use of trade, product, or firm names is for descriptive purposes only and does not imply endorsement by the U.S. Government.

Although this report is in the public domain, permission must be secured from the individual copyright owners to reproduce any copyrighted materials contained within this report.

Suggested citation:

Harte, P.T., 2010, Hydrostratigraphic mapping of the Milford-Souhegan glacial drift aquifer, and effects of hydrostratigraphy on transport of PCE, Operable Unit 1, Savage Superfund site, Milford, New Hampshire: U.S. Geological Survey Open-File Report 2010-1047, 34 p., 3 pls., at http://pubs.usgs.gov/of/2010/1047/. 


\section{Acknowledgments}

This study was conducted as part of the remedial effort at the Savage Municipal Well Superfund site and is a collaborative effort between Federal, State, and local governments, and private companies and individuals. The author wishes to thank Robin Mongeon and Thomas Andrews of the New Hampshire Department of Environmental Services (NHDES); Richard Goehlert, site remedial project manager of the U.S. Environmental Protection Agency (USEPA), Region 1; and Richard Willey, lead hydrogeologist, USEPA, Region 1, for their cooperation and support. Thanks to personnel at N.A. Water Systems, Inc., and Roy F. Weston, Inc., for much needed logistical assistance. Special thanks to Dr. Stephen L. Snyder of the U.S. Geological Survey, Reston, Va., who quantified concentrations of selected radioactive elements in sediment samples using gamma-ray spectrometry at his Reston laboratory. 
THIS PAGE INTENTIONALLY LEFT BLANK 


\section{Contents}

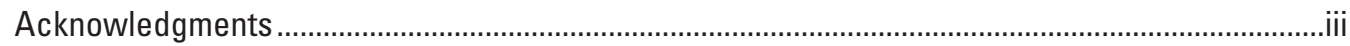

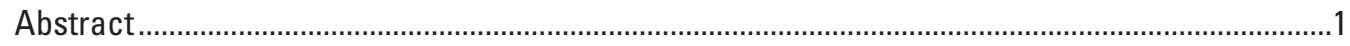

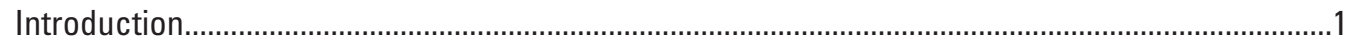

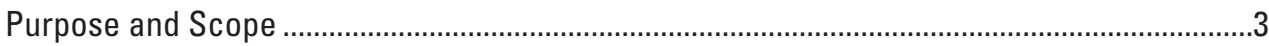

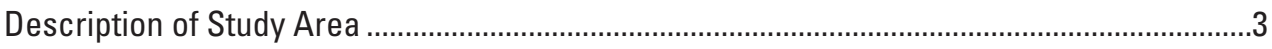

Previous Investigations of Operable Unit 1 (OU1) ...................................................................5

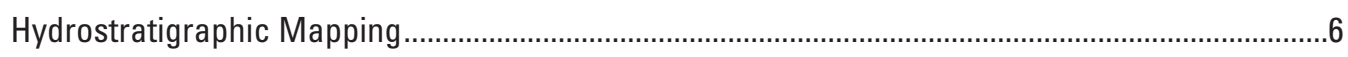

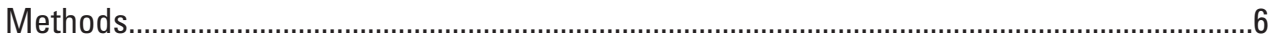

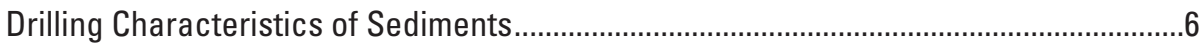

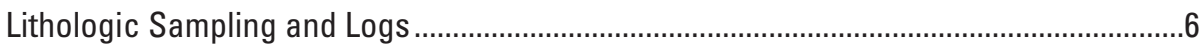

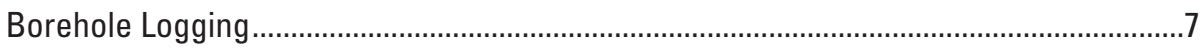

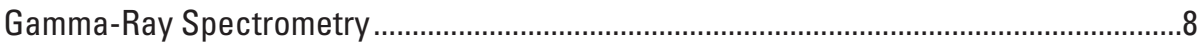

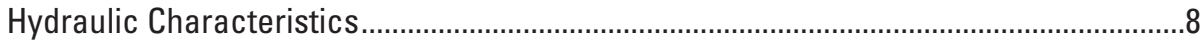

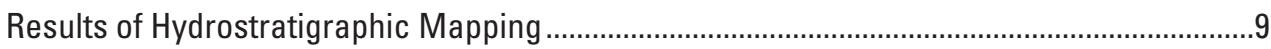

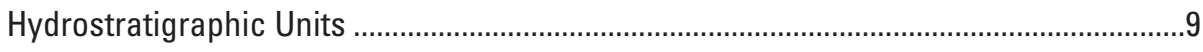

Gamma and Radioisotope Characteristics ...........................................................12

Hydraulic Characteristics...................................................................................... 12

Discussion of Hydrostratigraphic Units ................................................................ 14

Hydrostratigraphic Surface Maps ................................................................................. 15

Hydrostratigraphic Sections ......................................................................................20

Hydrostratigraphic Effects on Flow, Transport of PCE, and Remediation ....................................20

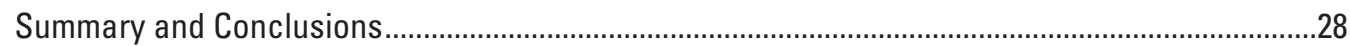

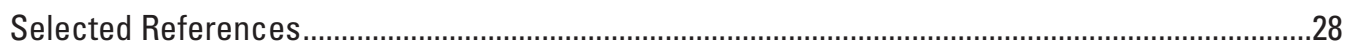

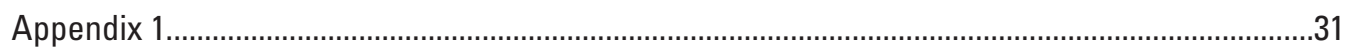

\section{Plates}

1a. Locations of groundwater wells, test boreholes, air sparge, and vapor extraction wells for Operable Unit 1 (OU1) of the Savage Municipal Well Superfund site, Milford, New Hampshire, Pre-2003

1b. Locations of groundwater wells, test boreholes, air sparge, and vapor extraction wells for Operable Unit 1 (OU1) of the Savage Municipal Well Superfund site, Milford, New Hampshire, 2003-08

2. Locations of vertical profile points and selected groundwater wells for Operable Unit 1 (OU1) of the Savage Municipal Well Superfund site, Milford, New Hampshire, 2008 


\section{Figures}

1. Location map of the volatile organic compound contaminant plume in 1994, Savage Municipal Well Superfund site, Milford, New Hampshire.

2. Map of Operable Unit 1 (OU1), remedial system, selected wells, 1995 contaminant plume of tetrachloroethylene (PCE), line of section A-A', Savage Municipal Well

Superfund site, Milford, New Hampshire

3. Logs of well PW-20D showing lithology, hydrostratigraphy, borehole natural gamma ray and electromagnetic conductivity in 2006, OU1 area, Savage Municipal Well

Superfund site, Milford, New Hampshire

4. Plot of borehole natural gamma-ray counts to corresponding thorium concentration per hydrostratigraphic unit, OU1 area, Savage Municipal Well Superfund site, Milford, New Hampshire

5. Contour map of altitude of top of bedrock surface, OU1 area, Savage Municipal Well Superfund site, Milford, New Hampshire.

6. Contour map of altitude of top of till surface, OU1 area, Savage Municipal Well Superfund site, Milford, New Hampshire

7. Contour map of basal till thickness, OU1 area, Savage Municipal Well Superfund site, Milford, New Hampshire

8. Contour map of altitude of bottom surface for hydrostratigraphic unit MS2, OU1 area, Savage Municipal Well Superfund site, Milford, New Hampshire.

9. Transverse cross section through OU1 showing lithology, OU1 area, Savage Municipal Well Superfund site, Milford, New Hampshire

10. Transverse cross section through OU1 showing borehole gamma-ray counts, OU1 area, Savage Municipal Well Superfund site, Milford, New Hampshire.

11. Transverse cross section through OU1 showing hydrostratigraphic units, OU1 area, Savage Municipal Well Superfund site, Milford, New Hampshire

12. Transverse cross section through OU1 showing 2007 PCE concentrations from wells, along with hydrostratigraphy, OU1 area, Savage Municipal Well Superfund site, Milford, New Hampshire.

13. Transverse cross section through OU1 showing 1996 PCE concentrations from vertical profiling of groundwater, along with hydrostratigraphy, OU1 area, Savage Municipal Well Superfund site, Milford, New Hampshire

14. PCE concentrations from vertical profiling and logs of borehole natural gamma-ray, lithologic, and hydrostratigraphic units at well PW-20D, OU1 area, Savage Municipal Well Superfund site, Milford, New Hampshire 


\section{Tables}

1. Lithologic codes and description of sediments, $0 \mathrm{U} 1$ area, Savage Superfund site, Milford, New Hampshire.

2. Hydrostratigraphic codes, unit names, and description, OU1 area, Savage Superfund site, Milford, New Hampshire.

3. Summary of unconsolidated hydrostratigraphic units and thickness, OU1 area, Savage Superfund site, Milford, New Hampshire.

4. Coefficients of determination and significance for correlation of radioactive element concentration and associated borehole natural gamma-ray count, OU1 area, Savage Superfund site, Milford, New Hampshire.

5. Mean concentration of analyzed radioactive elements for selected hydrostratigraphic units, OU1 area, Savage Superfund site, Milford, New Hampshire

6. Estimates of hydraulic conductivity from effective grain size (D90) for selected hydrostratigraphic units, OU1 area, Savage Superfund site, Milford, New Hampshire.14

7. Relative ranking of radioactive elements based on concentration, hydraulic conductivities, and borehole natural gamma-ray counts for selected hydrostratigraphic units, OU1 area, Savage Superfund site, Milford, New Hampshire

1-1. Comparison of grain-size-analysis methods from lithologic samples in the OU1 area, Savage Superfund site, Milford, New Hampshire.

1-2. Comparison of hydraulic conductivities between hydraulic tests of single wells and grain-size analyses, OU1 area, Savage Superfund site, Milford, New Hampshire. 


\section{Conversion Factors, Datum, and Abbreviations}

Inch/Pound to SI

\begin{tabular}{|c|c|c|}
\hline Multiply & By & To obtain \\
\hline \multicolumn{3}{|c|}{ Length } \\
\hline inch (in.) & 2.54 & centimeter $(\mathrm{cm})$ \\
\hline inch (in.) & 25.4 & millimeter $(\mathrm{mm})$ \\
\hline foot $(\mathrm{ft})$ & 0.3048 & meter $(\mathrm{m})$ \\
\hline mile (mi) & 1.609 & kilometer $(\mathrm{km})$ \\
\hline \multicolumn{3}{|c|}{ Area } \\
\hline square foot $\left(\mathrm{ft}^{2}\right)$ & 929.0 & square centimeter $\left(\mathrm{cm}^{2}\right)$ \\
\hline square foot $\left(\mathrm{ft}^{2}\right)$ & 0.09290 & square meter $\left(\mathrm{m}^{2}\right)$ \\
\hline square inch $\left(\mathrm{in}^{2}\right)$ & 6.452 & square centimeter $\left(\mathrm{cm}^{2}\right)$ \\
\hline square mile $\left(\mathrm{mi}^{2}\right)$ & 259.0 & hectare (ha) \\
\hline square mile $\left(\mathrm{mi}^{2}\right)$ & 2.590 & square kilometer $\left(\mathrm{km}^{2}\right)$ \\
\hline \multicolumn{3}{|c|}{ Volume } \\
\hline gallon (gal) & 3.785 & liter (L) \\
\hline gallon (gal) & 0.003785 & cubic meter $\left(\mathrm{m}^{3}\right)$ \\
\hline gallon (gal) & 3.785 & cubic decimeter $\left(\mathrm{dm}^{3}\right)$ \\
\hline million gallons (Mgal) & 3,785 & cubic meter $\left(\mathrm{m}^{3}\right)$ \\
\hline cubic foot $\left(\mathrm{ft}^{3}\right)$ & 28.32 & cubic decimeter $\left(\mathrm{dm}^{3}\right)$ \\
\hline cubic foot $\left(\mathrm{ft}^{3}\right)$ & 0.02832 & cubic meter $\left(\mathrm{m}^{3}\right)$ \\
\hline \multicolumn{3}{|c|}{ Flow rate } \\
\hline foot per second $(\mathrm{ft} / \mathrm{s})$ & 0.3048 & meter per second $(\mathrm{m} / \mathrm{s})$ \\
\hline foot per day (ft/d) & 0.3048 & meter per day $(\mathrm{m} / \mathrm{d})$ \\
\hline foot per year (ft/yr) & 0.3048 & meter per year (m/yr) \\
\hline cubic foot per second $\left(\mathrm{ft}^{3} / \mathrm{s}\right)$ & 0.02832 & cubic meter per second $\left(\mathrm{m}^{3} / \mathrm{s}\right)$ \\
\hline cubic foot per day $\left(\mathrm{ft}^{3} / \mathrm{d}\right)$ & 0.02832 & cubic meter per day $\left(\mathrm{m}^{3} / \mathrm{d}\right)$ \\
\hline gallon per minute (gal/min) & 0.06309 & liter per second $(\mathrm{L} / \mathrm{s})$ \\
\hline gallon per day (gal/d) & 0.003785 & cubic meter per day $\left(\mathrm{m}^{3} / \mathrm{d}\right)$ \\
\hline million gallons per day (Mgal/d) & 0.04381 & cubic meter per second $\left(\mathrm{m}^{3} / \mathrm{s}\right)$ \\
\hline inch per year (in/yr) & 25.4 & millimeter per year (mm/yr) \\
\hline \multicolumn{3}{|c|}{ Pressure } \\
\hline pound per square inch $\left(\mathrm{lb} / \mathrm{in}^{2}\right)$ & 6.895 & kilopascal (kPa) \\
\hline \multicolumn{3}{|c|}{ Mass } \\
\hline pound & 0.4536 & kilogram (kg) \\
\hline \multicolumn{3}{|c|}{ Specific capacity } \\
\hline $\begin{array}{l}\text { gallon per minute per foot } \\
[(\mathrm{gal} / \mathrm{min}) / \mathrm{ft})]\end{array}$ & 0.2070 & $\begin{array}{l}\text { liter per second per meter } \\
{[(\mathrm{L} / \mathrm{s}) / \mathrm{m}]}\end{array}$ \\
\hline \multicolumn{3}{|c|}{ Hydraulic conductivity } \\
\hline foot per day (ft/d) & 0.3048 & meter per day $(\mathrm{m} / \mathrm{d})$ \\
\hline \multicolumn{3}{|c|}{ Hydraulic gradient } \\
\hline foot per foot (ft/ft) & 0.3048 & meter per meter $(\mathrm{m} / \mathrm{m})$ \\
\hline foot per mile ( $\mathrm{ft} / \mathrm{mi})$ & 0.1894 & meter per kilometer $(\mathrm{m} / \mathrm{km})$ \\
\hline \multicolumn{3}{|c|}{ Transmissivity* } \\
\hline foot squared per day $\left(\mathrm{ft}^{2} / \mathrm{d}\right)$ & 0.09290 & meter squared per day $\left(\mathrm{m}^{2} / \mathrm{d}\right)$ \\
\hline
\end{tabular}


Temperature in degrees Celsius $\left({ }^{\circ} \mathrm{C}\right)$ may be converted to degrees Fahrenheit $\left({ }^{\circ} \mathrm{F}\right)$ as follows:

$$
{ }^{\circ} \mathrm{F}=\left(1.8 \times^{\circ} \mathrm{C}\right)+32
$$

Temperature in degrees Fahrenheit $\left({ }^{\circ} \mathrm{F}\right)$ may be converted to degrees Celsius $\left({ }^{\circ} \mathrm{C}\right)$ as follows:

$$
{ }^{\circ} \mathrm{C}=\left({ }^{\circ} \mathrm{F}-32\right) / 1.8
$$

Vertical coordinate information is referenced to the National Geodetic Vertical Datum of 1929 (NGVD 29).

Horizontal coordinate information is referenced to the North American Datum of 1983 (NAD 83).

Altitude, as used in this report, refers to distance above the vertical datum.

${ }^{*}$ Specific conductance is given in microsiemens per centimeter at 25 degrees Celsius $(\mu \mathrm{S} / \mathrm{cm}$ at $\left.25^{\circ} \mathrm{C}\right)$.

Concentrations of chemical constituents in water are given either in milligrams per liter $(\mathrm{mg} / \mathrm{L})$, approximately equivalent to parts per million (ppm), or micrograms per liter $(\mu \mathrm{g} / \mathrm{L})$, approximately equivalent to parts per billion (ppb).

\author{
ABBREVIATIONS AND EXPLANATIONS OF TERMS USED IN THIS REPORT: \\ cis-1,2-DCE cis-1,2-dichloroethene \\ DCE dichloroethene \\ DNAPL'S Dense Non-Aqueous Phase Liquids \\ INEEL Idaho National Engineering and Environmental Laboratory \\ MSGD Milford-Souhegan Glacial-Drift aquifer \\ OU1 Operable Unit \#1 of the Savage Municipal Well Superfund site \\ OU2 Operable Unit \#2 of the Savage Municipal Well Superfund site \\ PCE tetrachloroethylene \\ TCE trichloroethylene \\ TOC total organic carbon \\ VOC volatile organic compound
}

UNITS OF MEASUREMENT:

g grams

$\min \quad$ minute

yr year

WELL IDENTIFICATION, ABBREVIATIONS, AND EXPLANATION:

Well names used in this report typically are designated based on previous studies. 


\section{Prefix for remedial wells}

$\begin{array}{ll}\text { EW } & \text { exterior barrier wall extraction well } \\ \text { IW } & \text { interior barrier wall extraction well } \\ \text { RW } & \text { recharge well } \\ \text { SP } & \begin{array}{l}\text { air sparge well (used for remedial technology that reduces concentrations of } \\ \text { volatile contaminants adsorbed to soils and dissolved in groundwater in the } \\ \text { saturated zone; involves the injection of air into the saturated zone) }\end{array} \\ & \begin{array}{l}\text { soil vapor extraction well (used for remedial technology that reduces } \\ \text { concentrations of volatile contaminants adsorbed to soils in the unsaturated } \\ \text { zVEe; involves the extraction of air from the unsaturated zone) }\end{array}\end{array}$

\section{$\underline{\text { Miscellaneous }}$}

VP vertical profile

INEEL well located in INEEL well field

Prefix for observation wells

P piezometer

$\mathrm{PW}, \mathrm{B}, \mathrm{MI}$, and MW observation wells

\section{Suffix for observation wells}

D or C deep cluster well; typically set at depths greater than 70.1 feet below land surface

M or B medium cluster well; typically set at depths between 40.1 and 70.1 feet below land surface

$\mathrm{R} \quad$ bedrock well

S or A shallow cluster well; typically set at depths less than 40.1 feet below land surface

Selected lithologic abbreviations (Table 1 contains an expanded list)

C

coarse

f fine

m medium

Wx weathered

S sand

g gravel

sg sand and gravel

gs gravel and sand 


\title{
Hydrostratigraphic Mapping of the Milford-Souhegan Glacial Drift Aquifer, and Effects of Hydrostratigraphy on Transport of PCE, Operable Unit 1, Savage Superfund Site, Milford, New Hampshire
}

\author{
By Philip T. Harte
}

\section{Abstract}

The Savage Municipal Well Superfund site in the Town of Milford, New Hampshire, was underlain by a 0.5 -square mile plume (as mapped in 1994) of volatile organic compounds (VOCs), most of which consisted of tetrachloroethylene (PCE). The plume occurs mostly within highly transmissive stratified-drift deposits but also extends into underlying till and bedrock. The plume has been divided into two areas called Operable Unit 1 (OU1), which contains the primary source area, and Operable Unit 2 (OU2), which is defined as the extended plume area outside of OU1. The OU1 remedial system includes a low-permeability barrier wall that encircles the highest detected concentrations of PCE and a series of injection and extraction wells to contain and remove contaminants. The barrier wall likely penetrates the full thickness of the sand and gravel; in many places, it also penetrates the full thickness of the underlying basal till and sits atop bedrock.

From 1998 to 2004, PCE concentrations decreased by an average of 80 percent at most wells outside the barrier wall. However, inside the barrier, PCE concentrations greater than 10,000 micrograms per liter $(\mu \mathrm{g} / \mathrm{L})$ still exist (2008). The remediation of these areas of recalcitrant PCE presents challenges to successful remediation.

The U.S. Geological Survey (USGS), in cooperation with the New Hampshire Department of Environmental Services (NHDES) and the U.S. Environmental Protection Agency (USEPA), Region 1, is studying the solute transport of VOCs (primarily PCE) in contaminated groundwater in the unconsolidated sediments (overburden) of the Savage site and specifically assisting in the evaluation of the effectiveness of remedial operations in the OU1 area. As part of this effort, the USGS analyzed the subsurface stratigraphy to help understand hydrostratigraphic controls on remediation.

A combination of lithologic, borehole natural gamma-ray and electromagnetic (EM) induction logging, and test drilling has identified 11 primary hydrostratigraphic units in OU1.
These 11 units consist of several well-sorted sandy layers with some gravel that are separated by poorly sorted cobble layers with a fine-grained matrix. Collectively these units represent glacial sediments deposited by localized ice-margin fluctuations. For the most part, the units are semi-planar, particularly the cobble units, and truncated by an undulating bedrock surface. The lowermost unit is a basal till that ranges in thickness from zero to greater than 10 feet and mantles the bedrock surface.

The 11 units have different lithologic and hydraulic characteristics. The hydraulic conductivity of the well-sorted sand and gravel units is typically greater than the conductivity of the poorly sorted cobble units and the basal till. The hydraulic conductivity ranges from 5 to greater than 500 feet per day. Lateral and vertical variation in lithology and hydraulic conductivity are inferred by variations in borehole natural gamma-ray counts and estimates of hydraulic conductivity.

The comparison of hydrostratigraphic units with the spatial distribution of PCE concentrations suggests that solute transport away from source areas is primarily lateral within the permeable sandy units in the middle to lower parts of the aquifer. Along the centerline of the interior barrier area, highest PCE concentrations are in the sandy units to the east of suspected source areas.

\section{Introduction}

The Savage Municipal Well Superfund site (Savage site), named after a former municipal water-supply well (the Savage well) that served the Town of Milford, New Hampshire, is underlain by a 0.5 -square mile $\left(\mathrm{mi}^{2}\right)$ contaminant plume (as shown in 1994; fig. 1) of volatile organic compounds (VOCs), consisting primarily of tetrachloroethylene (PCE). The VOC plume is mostly within highly transmissive stratified-drift deposits and extends into the underlying till and bedrock. The stratified-drift deposits, part of the Milford-Souhegan-GlacialDrift aquifer (MSGD), are an important source of water for a 


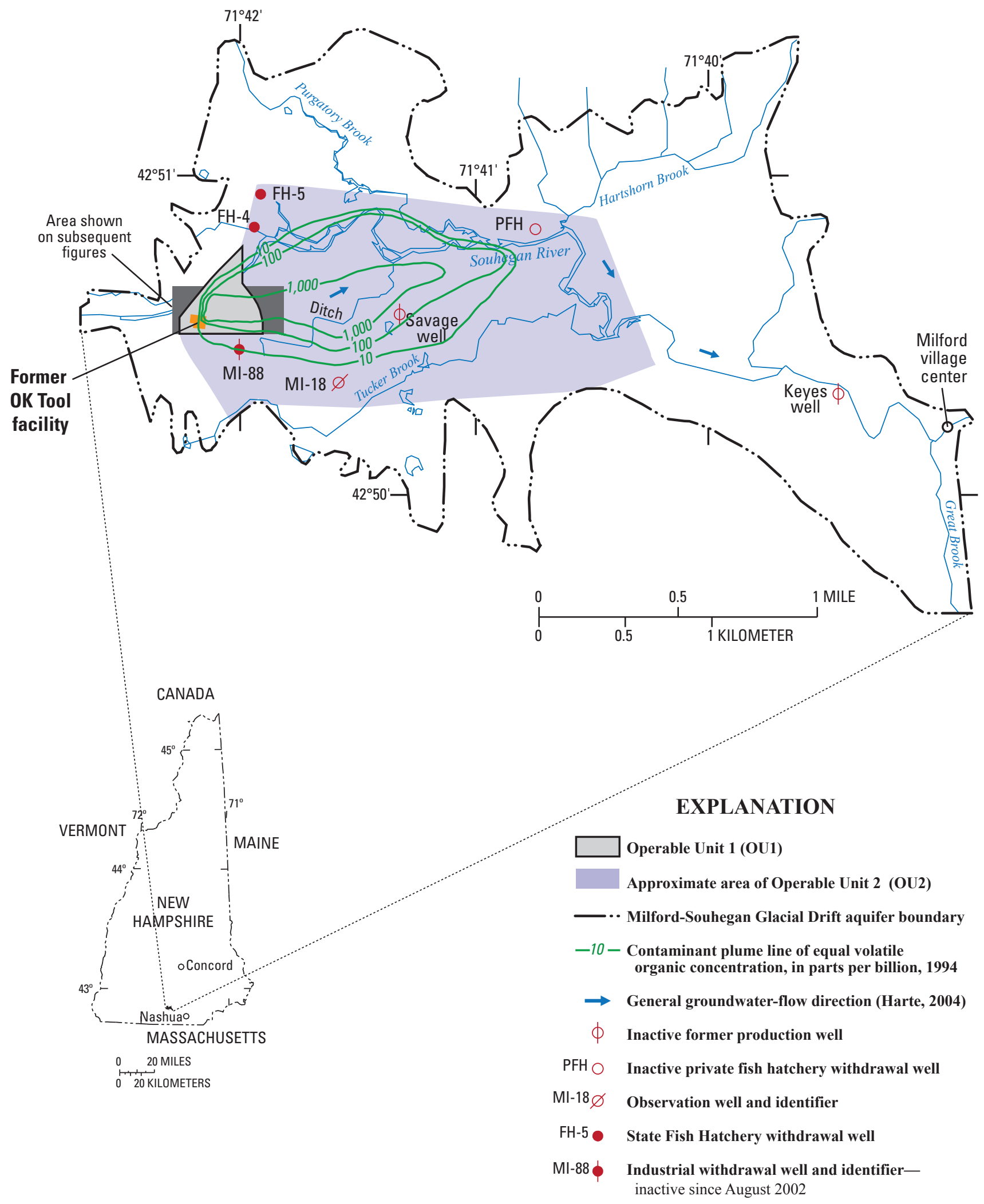

Figure 1. Location map of the volatile organic compound contaminant plume in 1994, Savage Municipal Well Superfund site, Milford, New Hampshire. 
New Hampshire State Fish Hatchery, which uses more than 2 million gallons per day (Mgal/d). Before contamination with VOCs, the aquifer also supplied more than $1 \mathrm{Mgal} / \mathrm{d}$ to two former municipal water-supply wells (the Savage well and a well outside of the study area (Keyes well)).

For remedial purposes, the plume is divided into two Operable Units. A discontinued tool manufacturing facility, the OK Tool facility, is part of Operable Unit 1 (OU1) and has been identified as the primary source area of the contaminant plume containing PCE that led to the contamination of the Savage well (HMM Associates, Inc., 1989; 1991). The contaminant plume downgradient of OU1 is designated as Operable Unit 2 (OU2), also called the extended plume area.

The State of New Hampshire Department of Environmental Services (NHDES) and the U.S. Environmental Protection Agency (USEPA), Region 1, have constructed a remedial system for the OU1 area (fig. 2). The remedial system consists of a low-permeability barrier wall, which surrounds the highest concentrations of dissolved PCE and, most likely, some Dense Non-Aqueous Phase Liquid (DNAPL), and various injection (including a recharge gallery; fig. 2) and extraction wells (vapor and water) to capture and treat the dissolved contaminants. Several previously identified source areas are shown in figure 2 where contaminant disposal has been identified (Camp, Dresser, and McKee, Inc., Federal Programs Corporation, 1995). The barrier wall was constructed from July to November 1998. Remedial operations of wells were tested from December 1998 to March 1999. Full remedial operation started in May 1999.

In 1995, maximum concentrations of PCE, the primary contaminant, ranged up to 100,000 micrograms per liter $(\mu \mathrm{g} / \mathrm{L})$ in areas now inside the barrier wall to $10,000 \mu \mathrm{g} / \mathrm{L}$ in areas now outside the wall (Camp, Dresser, and McKee, Inc., Federal Programs Corporation, 1995). Concentrations of secondary VOCs (TCE and cis-1,2-DCE) were typically one to two orders of magnitude less than those of PCE (Harte and others, 2001).

Remediation and containment have led to PCE concentration declines in parts of OU1. From 1999 to 2007, the mass of dissolved VOCs captured, extracted, and treated totaled 2,431 pounds (N.A. Water Systems, 2007). From 2003 to 2004, additional destruction of VOCs from Insitu Chemical Oxidation (ISCO) treatment of target areas inside the barrier was estimated at 247 pounds (N.A. Water Systems, 2006a). Outside of the barrier, PCE concentrations have declined to less than $10 \mu \mathrm{g} / \mathrm{L}$ over a large area of OU1 (as of 2008). Inside the barrier, PCE concentrations have declined to less than $10,000 \mu \mathrm{g} / \mathrm{L}$ over some areas. Despite these successes, remediation of areas of recalcitrant PCE still presents new challenges.

The U.S. Geological Survey (USGS), in cooperation with the NHDES and the USEPA, Region 1, conducted a study of the stratigraphy of the MSGD aquifer at the OU1 area to (1) establish a framework for understanding solute transport of VOCs (primarily PCE), (2) assess spatial and temporal concentration patterns of PCE, and (3) provide information to help remedial managers develop remedial strategies for addressing residual pockets of PCE. The establishment of this framework is herein termed "hydrostratigraphic mapping."

\section{Purpose and Scope}

This report presents methods and findings from the hydrostratigraphic mapping of subsurface sediments for the OU1 area from 2004 to 2008. Included is a discussion of the various techniques used in this investigation (lithologic sampling and characterization, test drilling, and borehole logging). Important results are highlighted and implications for remedial strategies are discussed. The spatial distribution of PCE concentrations was compared to the hydrostratigraphic framework to identify potential source locations for PCE and solute-transport processes (advection, dispersion, diffusion, retardation, and degradation).

\section{Description of Study Area}

The OU1 study area is delineated in figure 1 and covers a "pie"-shaped area in the western part of the Souhegan River Valley and MSGD aquifer area. This section includes a description of the river valley and MSGD aquifer area (generally coincident), and of the OU1 study area. The MSGD aquifer is defined as the entire sequence of unconsolidated sediments overlying (overburden) the bedrock in the Souhegan River Valley of Milford, New Hampshire.

The Souhegan River Valley slopes gently to the east at approximately $12 \mathrm{ft}$ per mile (ft/mi) along the Souhegan River. Land-surface altitudes range from 230 to $280 \mathrm{ft}$ (above NGVD 29 ) in the valley, and water drains to the Souhegan River and its tributaries, including Tucker, Purgatory, Great, and Hartshorn Brooks and a number of small, unnamed streams (fig. 1). A discharge ditch drained processed waters from a manufacturing company in the southwestern part of the study area until operations terminated in August 2002.

Land use overlying the MSGD aquifer is predominantly industrial in the southwestern area, agricultural in the central and northwestern areas, and residential and commercial elsewhere. The contaminant plume underlies a large agricultural area (not shown on any figures) and abuts a commercialindustrial area to the south (not shown on any figures).

Groundwater withdrawals from the MSGD aquifer in 2001 were used primarily for commercial and industrial purposes. Two wells for the State Fish Hatchery in the northwestern part of the study area (wells FH-4 and FH-5, fig. 1) withdraw more than $2 \mathrm{Mgal} / \mathrm{d}$. Consumptive use is small because most of the withdrawn water is returned to Purgatory Brook (fig. 1). An inactive withdrawal well at a private fish hatchery (PFH, fig. 1) in the eastern part of the study area withdrew $0.14 \mathrm{Mgal} / \mathrm{d}$ until the late 1990s. An inactive (as of August 2002) withdrawal well (MI-88, fig. 1) at an industrial complex in the southwestern part of the study area withdrew about $0.25 \mathrm{Mgal} / \mathrm{d}$, as reported in 1995 . 


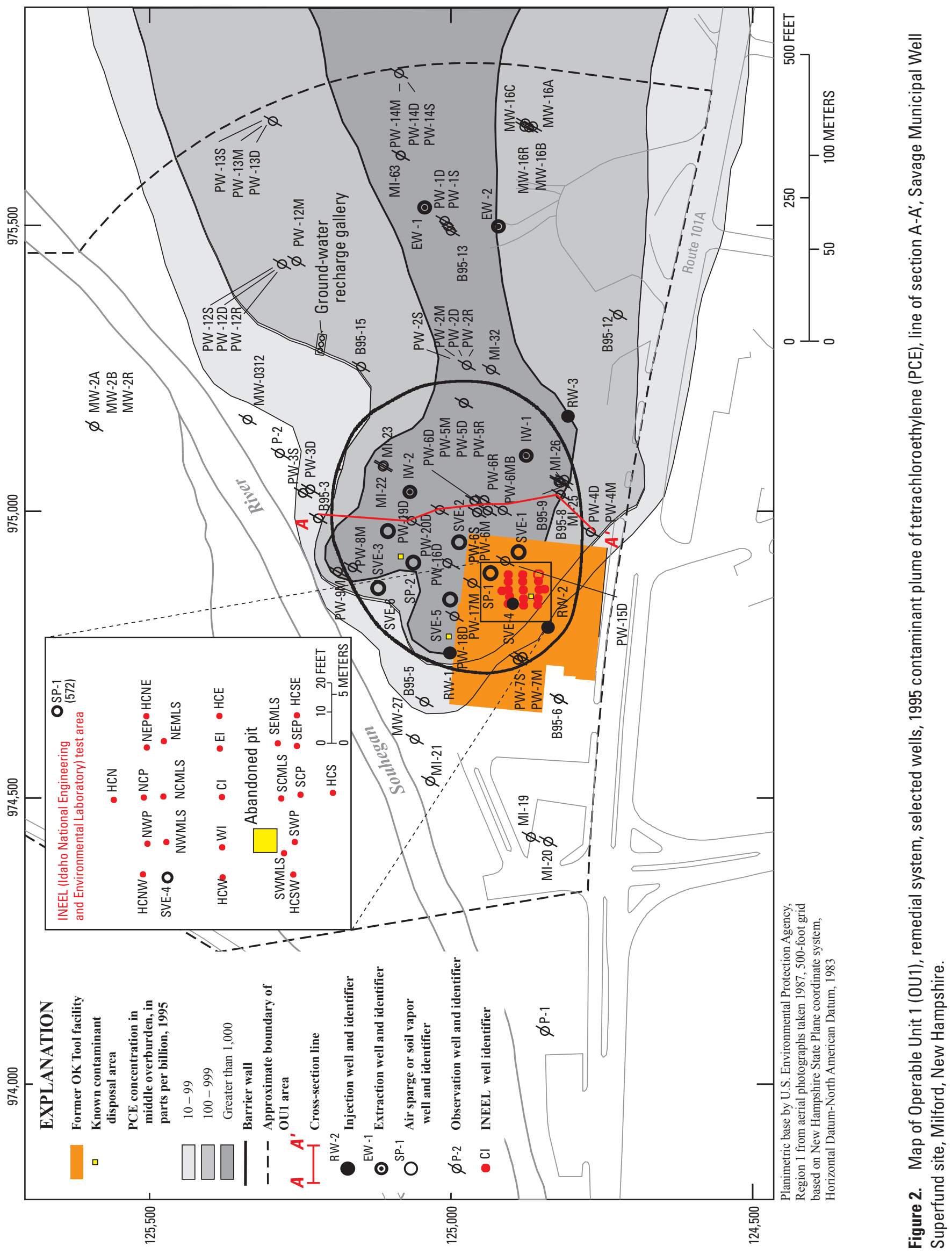


The effluent from this well was formerly discharged to the aforementioned drainage ditch (Ditch; fig. 1).

Solvents were discharged into the subsurface at the OK Tool facility for approximately 35 years until the early 1980s (HMM Associates, Inc., 1989; 1991). Although discharges have ceased, the underlying contaminant-soaked sediments and immiscible solvents (most likely DNAPLs) continued to contaminate groundwater flowing easterly underneath the site until a barrier wall was constructed in 1998 .

The barrier wall (referred to as "barrier" in this report) is constructed of low-permeability materials (bentonite clay) and is designed to contain the highest concentrations of VOCs from being transported into the aquifer. The barrier encircles a 166,000-square foot $\left(\mathrm{ft}^{2}\right)$ area. In general, the barrier fully penetrates the sand and gravel layers and in some places the underlying till, to the bedrock surface. The barrier was designed to penetrate at least $3 \mathrm{ft}$ into the basal till, but in many locations this minimum depth was exceeded. An analysis of barrier wall depth is provided in Harte (2006). Various injection and extraction wells (fig. 2) were installed to insure hydraulic isolation, reduce contaminant mass inside the barrier wall, and capture and treat the contaminants outside the barrier. Exterior extraction wells were operated from 1999 until April 2007 when effluent PCE concentrations from these wells approached remedial clean-up levels (less than $10 \mu \mathrm{g} / \mathrm{L}$ ). Interior extraction continued (as of 2008) to insure hydraulic containment inside the barrier and to promote inward hydraulic gradients across the barrier.

Groundwater flow and solute transport were west to east prior to construction and operation of the remedial system. The Souhegan River in this area is a losing river reach (Harte and Mack, 1992), and recharge from the river is an important component of the groundwater budget. After the remedial system was installed and after commencement of remedial operation, local flow patterns changed. During operation of remedial extraction wells inside the barrier, inward flow across the barrier generally occurs for conditions with a minimum net extraction of 20 gallons per minute ( $\mathrm{gal} / \mathrm{min}$ ), and flow directions locally are opposite the regional flow patterns (Harte, 2006).

Three primary VOC sources have been identified inside the barrier area in OU1 (Camp, Dresser, and McKee, Inc., 1996). They include a floor drain inside the former "destroyed" building near a degreasing tank (called "abandoned pit area"), a leach field north of the former building, and an area northwest of the former building near a former degreasing tank. The abandoned pit area (southernmost location in fig. 2 and identified as the contaminant disposal area in the figure inset) is believed to be the primary source input location based on concentrations of PCE in the soil and concentrations of PCE in groundwater samples from observation wells and vertical profile points (Guilbeault and others, 1997; 1998). The locations of these data points are shown in figure 2 and on plates $1 \mathrm{a}, 1 \mathrm{~b}$, and 2 .

\section{Previous Investigations of Operable Unit 1 (OU1)}

The abandoned pit area in the INEEL (Idaho National Engineering and Environmental Laboratory, named after the lead investigative agency studying the pit area) well field has been the focus of most investigations of contaminant source characterization (fig. 2). Investigations determined that the distribution of PCE is complex and characterized by relatively thin, 3 to $15 \mathrm{ft}$-thick zones of high PCE concentrations (greater than $10,000 \mu \mathrm{g} / \mathrm{L}$ ) at depths of 15 to $60 \mathrm{ft}$ below land surface, interspersed within zones of lower PCE concentrations (less than $10,000 \mu \mathrm{g} / \mathrm{L})$. The variable PCE distribution suggests that aquifer heterogeneity is also complex. Guilbeault and others $(1997$; 1998) suggest aquifer porosity as a possible controlling mechanism affecting DNAPL distribution and dissolved PCE concentrations. Harte and others (2002) and Harte (2008) determined that high PCE concentrations were associated with stratigraphic contacts between different lithologies.

Most of the information regarding PCE distribution in OU1 was initially obtained from vertical profiling of the INEEL field area. Vertical profiling of groundwater by use of a direct-push profiler was performed on multiple occasions by the University of Waterloo in 1994, 1995, 1997, and 1998 (Guilbeault and others, 1997; 1998) to map subsurface contamination (vertical profile points shown on plate 2). In 1994-95, profiling detected PCE concentrations exceeding $100,000 \mu \mathrm{g} / \mathrm{L}$ at a $19-\mathrm{ft}$ depth below land surface at profile point VP-1008 (plate 2), located approximately $20 \mathrm{ft}$ south of the abandoned pit area (Camp, Dresser, and McKee, Inc., Federal Programs Corporation, 1995). In 1997, a line of profile points was completed about $17 \mathrm{ft}$ downgradient (east) of the pit location; this profiling detected maximum PCE concentrations of approximately $70,000 \mu \mathrm{g} / \mathrm{L}$ (profile point SMI; plate 2) at a depth of $53 \mathrm{ft}$ below land surface (Guilbeaut and others, 1997). The depths of maximum PCE concentrations increase to the northeast with the primary groundwater-flow direction but also are controlled by the heterogeneity of the subsurface. In 1998, vertical profile points were installed laterally and upgradient to the pit. These profile points intercepted maximum PCE concentrations exceeding $100,000 \mu \mathrm{g} / \mathrm{L}$ (profile point SMN; plate 2) at depths less than $40 \mathrm{ft}$ below land surface (Guilbeaut and others, 1998).

On the basis of profiling results, 17 long-screened (45-ft) wells were installed near the abandoned pit area (fig. 2 insert). The assembly of wells is referred to as the INEEL well field (Tetra Tech EM, Inc., 2003). In addition to the 17 long-screened wells (fig. 2 insert), 6 multi-level sampler wells (designated by " $\mathrm{mls}$ " in the last three letters of the identifier in fig. 2 inset) also were installed. The multi-level samplers have sample intakes at depths of $22,28,42,48,58.5$, and $60.5 \mathrm{ft}$ below land surface.

The study of the INEEL well field included collection of two core holes, slug tests of INEEL wells, and a series of primarily conservative interwell tracer tests (CITT) in three zones of the overburden (shallow, middle, and deep) (Tetra Tech EM, Inc., 2003). Results of the CITT tracer tests 
showed substantial (more than a factor of 10 in hydraulic conductivity) horizontal and vertical heterogeneity. Estimates of hydraulic conductivity ranged from 28 to $574 \mathrm{ft} / \mathrm{d}$ with an average porosity of 0.25 (Tetra Tech EM, Inc., 2003). A partioning interwell tracer test (PITT) also was performed to measure residual DNAPL saturation and showed substantial heterogeneity in the distribution of DNAPL saturation (Tetra Tech EM, Inc., 2003).

The USGS collected a string of vertical, closely spaced $(2 \mathrm{ft})$ passive diffusion bag samples inside several INEEL wells to measure vertical distribution of PCE (Harte and others, 2002). The highest PCE concentrations (greater than $10,000 \mu \mathrm{g} / \mathrm{L}$ ) were associated with depths corresponding to the till surface at approximately 50 to $60 \mathrm{ft}$ below land surface.

Other studies by the USGS include construction and calibration of two groundwater-flow models (Harte and others, 1999; Harte and Mack, 1992), evaluation of the effects of groundwater withdrawals on advective transport of contaminated groundwater (Harte and Willey, 1997), analysis of PCE trends for pre- and post-barrier conditions (Harte and others, 2001), and description of a monitoring program of continuous water levels from water years 1997-2003 (Brayton and Harte, 2001; and Harte, 2005). Simulation of solute transport of PCE for the OU1 and OU2 areas is described in Harte (2004), and testing of remedial hydraulic operational schemes is described in Harte (2006).

Harte (2006) reported that the capture areas for the interior barrier extraction wells are smaller than anticipated because of groundwater upflow from the underlying bedrock, based on numerical groundwater-flow simulations of remedial operations. The hydraulic connection between the overburden and underlying bedrock was identified from water-level responses during remedial operations (Brayton and Harte, 2001; and Harte, 2005).

The subsurface investigations over the years at OU1 have resulted in a number of test boreholes, wells, and vertical profile points. Semi-chronological groupings of these data points, pre- and post-2003, are shown in plates $1 \mathrm{a}, 1 \mathrm{~b}$, and 2 .

\section{Hydrostratigraphic Mapping}

Hydrostratigraphic units are geologic units grouped by similar hydrogeologic properties (Porges and Hammer, 2007). Hydrostratigraphic mapping is the spatial delineation of these units. Several methods were used during this study to characterize and map hydrostratigraphic units. Results of the mapping were compared to estimates of hydraulic characteristics and contaminant transport of VOCs (PCE) to provide a hydrostratigraphic framework that can be used by site managers to evaluate remedial efforts.

\section{Methods}

Hydrostratigraphic mapping included the use of lithologic logs from drilling and borehole geophysical logging to differentiate subsurface units for characterization of hydraulic properties, groundwater flow, and transport of PCE. Test drilling was performed to identify compactness of units based on drilling resistance, and to install observation wells. Borehole geophysical logging included natural gamma-ray and electromagnetic induction (EM) logging. Selected sediment samples were analyzed with a gamma-ray spectrometer to identify units and their potential natural gamma-ray response.

Delineation of hydrostratigraphic units was facilitated by the use of several interpolation techniques. Spatial maps of surfaces of hydrostratigraphic units were generated using a gridded algorithm and interpolated with kriging methods. Three-dimensional models of gamma-ray counts and PCE concentrations were made using a horizontal-bias method of inverse-distance weighting.

\section{Drilling Characteristics of Sediments}

Several types of drilling have been performed at the study site. The most recent (2004-2008) drilling was done with a CME-55 auger rig operated by the USGS. Most of the USGS test drilling (26 out of 27) used a hollow-stem auger method. One test hole was drilled with a drive and wash casing to allow for installation of a 4-in. polyvinyl chloride (PVC) observation well. Twenty-three, 2-in. diameter, PVC observation wells were installed as part of this test-drilling effort.

The advantage in use of the auger method is that resistive "hard to drill" layers in the subsurface are easily identifiable. Coarse gravels and larger-size sediments (for example, cobbles) cause vibration on the end of the auger bit, and advancement into the subsurface is slowed. During drilling, these intervals were noted and compared to natural gammaray logs of the borehole (well) to facilitate mapping of the hydrostratigraphic units. In contrast, well-sorted fine gravel and smaller-size sediments were easily penetrated with auger drilling.

\section{Lithologic Sampling and Logs}

The lithology of the OU1 area was reported from drilling $\operatorname{logs}$ of wells and boreholes. The reliability of lithologic descriptions from logs is related, in part, to the type of drilling and lithologic sampling. Wells and boreholes designated with "MI" (fig. 2, plates 1a and 1b) were drilled in the early to mid1980s using unknown methods. However, lithologic samples were often collected with spoon samples as reported on logs. Wells and boreholes designated with a " $\mathrm{B}$ " were drilled by the drive and wash method. Lithologic samples were collected continuously with split-spoon samples for wells numbered 1 through 8 and discontinuously, every $5 \mathrm{ft}$ on center, for wells numbered 9 through 17 . Wells and boreholes designated with a 
"PW" (fig. 2, plates 1a and 1b) and numbered from 1 through 14 were drilled with an air rotary/barber rig. Lithologic samples were primarily collected by grab samples. Wells and boreholes designated with a "PW" and numbered 15 and greater were drilled with hollow-stem auger by the USGS. Lithologic samples were collected by split-spoon (in situ) and grab-type methods (ex situ) from auger spin material as sediments were removed from the hole. The reliability of auger spin materials as representative samples is dependent on a number of factors, including the overlying stratigraphy and the ability of sediments to be removed by the auger. Grab samples were collected at intervals that were believed to be representative of a given depth penetrated by the auger. Furthermore, the grab samples represent a composite non-directional sample.

For this study, an abbreviated lithologic coding system was used to describe and interpret lithologic logs (table 1). The coding is based on the predominant sediment type encountered. For example, several codes were used to describe sand and gravel deposits and these codes start with an "s" or "g," whichever is the predominant sediment type.

\section{Borehole Logging}

The two primary borehole-logging techniques used were natural gamma-ray logging and EM conductivity. A description of each technique and application follows.

Natural gamma-ray logging has been performed at most wells in OU1 in order to map out the subsurface stratigraphy of the unconsolidated sediments underlying the site. Natural gamma-ray logs measure natural radioactivity in formations adjacent to the well, and therefore, can be used to identify lithology. The most important naturally occurring gammaemitting radioactive elements include potassium-40 and daughter products of the uranium and thorium-decay series (Keys, 1990). Uranium (U) and thorium (TH) are concentrated in clay by the processes of adsorption and ion exchange. Thus, fine-grained sediments that contain clay tend to be more radioactive than "clean" (well washed with little fines) sands. Other formations besides those containing fine-grained sediments can emit high gamma radioactivity if they contain large amounts of radioactive elements.

Table 1. Lithologic codes and description of sediments, OU1 area, Savage Superfund site, Milford, New Hampshire.

[Grain size based on Wentworth (1922)]

\begin{tabular}{|c|c|}
\hline Code & Description of lithology \\
\hline TOPSOIL & Topsoil; uppermost soil encountered, typically sandy with limited organic detritus. \\
\hline COBBLES & $\begin{array}{l}\text { Large cobbles to fine sand matrix. Can have well-sorted sand lenses but generally poorly sorted matrix } \\
\text { with silt- to gravel-size sediments. Can include small boulders. }\end{array}$ \\
\hline GS & $\begin{array}{l}\text { Gravel and sand layer; gravel fine to coarse, and sand fine to coarse grained. Varying amounts of fine- } \\
\text { grained sediments (fine sand and silt). }\end{array}$ \\
\hline BOULDERS & Large boulders. \\
\hline SG & Sand, fine to coarse; with gravel, fine to coarse. \\
\hline OVERBURDEN & Unknown lithologic material. \\
\hline GRAVEL & Primarily a well-sorted fine to coarse gravel layer with some sand. \\
\hline SAND & Sand, fine to coarse but typically medium to coarse sand; well sorted. \\
\hline SILT & Silt lens typically thin (less than 1 foot layers). \\
\hline FS & Sand, very fine to fine; can contain some silt. \\
\hline VFS & Sand, very fine. \\
\hline UPPER TILL & $\begin{array}{l}\text { Older drilling logs indicate some poorly sorted units as an upper till sequence. This unit was character- } \\
\text { ized as grey to brown, poorly sorted, with fine to coarse sand and gravel. }\end{array}$ \\
\hline GRADATION & Layer with gradational sand that changes with depth. \\
\hline TILL & $\begin{array}{l}\text { Poorly sorted basal till except in western part of OU1 where it is thicker with some sand lenses. Lower } \\
\text { till is very dense grey silt with some sand and clay. }\end{array}$ \\
\hline WB & Weathered bedrock. \\
\hline BEDROCK & Bedrock, typically granite. \\
\hline REFUSAL & $\begin{array}{l}\text { Hard resistive layer encountered while drilling that prevents advance. Can be till, bedrock surface, or a } \\
\text { large boulder interpreted near the bedrock. }\end{array}$ \\
\hline
\end{tabular}


Low gamma-ray counts recorded for this study corresponded to well sorted sands and gravels and are an indicator of relatively more permeable units. In contrast, high gamma-ray counts can be associated with poorly sorted, less permeable units but also can be associated with coarsergrained sediments and more permeable units that contain relatively large amounts of radioactive elements.

Well construction affects gamma-ray emissions. Well diameter, casing and screen material, and grout used in the annulus of the borehole outside of the casing can affect readings. Large-diameter, (greater than 5 in.) steel-cased wells were found to reduce gamma-ray counts by 20 percent and more. For this reason, greater emphasis was placed on the use of borehole logs from PVC observation wells than on those from wells constructed of other material.

The spatial distribution of gamma-ray counts was analyzed in order to infer the hydrostratigraphy of OU1. Spatial patterns of gamma-ray counts were mapped with Rockware software, using a form of inverse-distance method called horizontal bias. The horizontal bias method limits vertical distances in which the gamma-ray count will affect the adjacent count during the interpolation process. A vertical to horizontal distance ratio of 1 to 2 was used to reduce vertical interpolation to one-half the horizontal. This geometry favors interpolation of values to represent more realistic conditions such as that found in layered stratified deposits.

Electromagnetic (EM) induction logging delineates changes in rock type or in the electrical properties of fluids in the rock formation by measuring the bulk apparent conductivity of the formation and pore fluids surrounding the borehole. The conductivity of the formation is measured using a magnetic field to induce an electric field, which in turn produces electric currents in the formation (Mount Sopris Instruments, Inc., 2002). EM induction measurements can be made in water-, air-, and mud-filled holes and through PVC casing. Major factors that affect induction-log response in sand-and-gravel aquifers are the concentration of dissolved solids (conductivity) in the groundwater and the silt and clay content of the aquifer (Williams and Lane, 1998).

EM logs were run in combination with gamma logs to identify the lithology and zones of electrically conductive groundwater from salting of nearby roads, permanganate from ISCO treatment, and chloride breakdown products from ISCO treatment of VOCs. Relatively high EM readings corresponded to clean sandy units with low gamma-ray count readings and, therefore, indicated relatively more permeable units with conductive groundwater.

\section{Gamma-Ray Spectrometry}

Radioactive elements of the potassium-40 (K) and daughter products of the uranium (U) and thorium (TH) decay series affect gamma-ray counts recorded during borehole logging (Keys, 1990). Although there is a strong relation between fine-grained sediments and high gamma-ray counts, other sediment types, such as boulders, can contain an abundance of high radioactive elements if the parent rock material contains high concentrations of these elements. Therefore, to assist in mapping of hydrostratigraphic units, lithologic samples collected as part of the test-drilling program for OU1 were analyzed by gamma-ray spectrometry (Stephen Synder, U.S. Geological Survey, written commun., 2007) to quantify the amount of TH, K, and $\mathrm{U}$ in sediments. A total of 25 lithologic samples were analyzed, including 1 topsoil, 4 upper cobble layer, 18 sand and gravel, and 2 basal till samples from test drilling inside the barrier.

Gamma-ray spectrometry measures the gamma rays emitted by radioactive elements that are present in solid and liquid samples. For this work, only three radioisotopes, $\mathrm{K}, \mathrm{TH}$, and $\mathrm{U}$, were analyzed. The spectrometer yields results for $\mathrm{K}$ in percent of sediment, and for TH and $\mathrm{U}$ in parts per million (ppm). These units of measurement are related to gamma-ray counts and can be converted to gamma-ray counts directly using a linear-least squares fitting program after factoring in known background corrected count rates for these elements (Steve Synder, U.S. Geological Survey, written commun., 2007).

Concentrations of $\mathrm{K}, \mathrm{U}$, and $\mathrm{TH}$ determined from gamma-ray spectrometry measurements were compared semi-quantatively to borehole gamma-ray counts for the same sample depths to evaluate the variability of concentrations in sediment types. Results were grouped by hydrostratigraphic units that were determined from the gamma logs, drilling characteristics, and lithology to identify trends in radioactive elements and associated gamma-ray counts.

\section{Hydraulic Characteristics}

Hydraulic characteristics (primarily hydraulic conductivity) were not used to directly map hydrostratigraphic units but were evaluated in relation to the mapped hydrostratigraphic units. For this study, the spatial frequency of measurements of hydraulic characteristics was insufficient for use as a mapping tool because most measurements were discrete and coarsely spaced (tens of feet apart). However, the subsurface geology was differentiated and mapped with the objective of identifying units with potentially different hydraulic characteristics.

Hydraulic characteristics, primarily hydraulic conductivity, were compiled from a variety of sources and techniques. Additional information on hydraulic characteristics also was collected as part of this study and compared to the mapped hydrostratigraphic units.

Hydraulic testing based on single-well, constant-head tests of observation wells (13 tests in total) was completed by Camp, Dresser, and McKee, Inc. (1996) at observation wells designated with the letter "B." Camp, Dresser, and McKee, Inc. (1996) also performed grain-size analysis, the results of which were used in this study to estimate hydraulic conductivity using methods discussed in the following paragraphs. Hydraulic testing, based on constant-head tests of four other observation wells, was conducted by Harding ESE, Inc. (2002). 
Slug tests were performed on selected wells to obtain hydraulic conductivity estimates. Both air and water slug displacement were used, and rates of water-level changes were recorded. Slug tests were analyzed according to methods described by Halford and Kuniansky (2002).

Continuous profiles of the hydraulic conductivity index (unit less, relative value) were done outside the barrier as part of a vertical profiling program by Camp, Dresser, and McKee, Inc. (2001) using a Waterloo profiler. The profiles provide a relative, not absolute, measure of hydraulic conductivity.

Pump tests (N.A. Water Systems, 2003 and 2005) had been performed at several extraction wells (EW-1 and EW-2; fig. 2) and selected wells (SVE-5 and HCNE) inside the barrier. Other hydraulic tests included a tracer demonstration program in the INEEL field (Tetra Tech EM, Inc., 2003).

Hydraulic conductivity estimates were developed from 25 lithologic samples, collected from inside the barrier as part of this study, and based on dry sieve grain-size analysis and methods described by Olney (1983). Estimates of hydraulic conductivity from grain-size analysis provide a non-directional measurement because the sediment structure is disturbed during collection and the sieving process (Chen, 2000). Two ranges of effective grain size were used to estimate hydraulic conductivity: $D 90$ (90 percent of grain-size coarser) and $D 75$ (75 percent of grain-size coarser). Both $D 90$ (smaller grain size) and $D 75$ (larger grain size) were found to correlate with independent (variable-head and constant-head permeameter tests) computation of hydraulic conductivity in a study by Olney (1983), and therefore, both are provided. The Olney (1983) regression analysis equations are

$$
K(D 90)=2,100(10)^{-0.655(D 90)},
$$

and

$$
K(D 75)=1,655(10)^{-0.730(D 75)}
$$

where

$$
\begin{aligned}
K & =\text { hydraulic conductivity, in } \mathrm{ft} / \mathrm{d} \text { for the } \\
& \text { respective grain size; } \\
D 90 \quad= & 90 \text { percent of grain-size coarser; and } \\
D 75 & =75 \text { percent of grain-size coarser. }
\end{aligned}
$$

Estimates of hydraulic conductivity also were compared to estimates from two other grain-size methods as described by Krumbein and Monk (1942) and Alyamani and Sen (1993).

The equation from Krumbein and Monk (1942) is

$$
\begin{gathered}
K=\text { intrinsic permeability }(\text { in Darcies })= \\
760(G M d)^{2} * e^{-1.31 s d},
\end{gathered}
$$

where

$$
\begin{array}{cc}
\text { GMd } & \text { geometric mean grain diameter, in } \\
& \text { millimeters (mm); and } \\
\text { sd } & \text { standard deviation, in phi units. }
\end{array}
$$

Intrinsic permeability can be converted to hydraulic conductivity by multiplying by the viscosity of water at a reference temperature and dividing by water density at same reference temperature and gravity constant. Table 2.3 of Freeze and Cherry (1979, p. 29) provides conversion factors for converting intrinsic permeability to hydraulic conductivity.

The equation from Alyamani and Sen (1993) is

$$
\begin{gathered}
K=\text { hydraulic conductivity in } \mathrm{m} / \mathrm{d}= \\
1,300[I o+0.025(D 50-D 90)]^{2},
\end{gathered}
$$

where

$$
\begin{aligned}
\text { Io } & =\text { intercept of slope of percent finer grain size, } \\
& \text { in mm; } \\
D 50 & =50 \text { percent coarser grain size, in } \mathrm{mm} \text {; and } \\
D 90 & =90 \text { percent coarser grain size, in } \mathrm{mm} .
\end{aligned}
$$

\section{Results of Hydrostratigraphic Mapping}

The physical, radioactive, and hydraulic characteristics of the subsurface stratigraphy for the study area are discussed in the following sections of the report. Selected examples are provided to highlight major features.

\section{Hydrostratigraphic Units}

The stratigraphy of OU1 was analyzed based on the assemblage of hydrostratigraphic units, which were differentiated and mapped with the objective of identifying units with potentially different hydraulic characteristics (table 2). Primarily 11 hydrostratigraphic units were identified as areally extensive within the inside barrier area. Other units also were noted, although less frequently, including very fine sand (vfs) and weathered bedrock (wx). A "hydrostratigraphic-type log" from well PW-20D is provided showing the 11 primary units (fig. 3). Well PW-20D is located near the middle of the OU1 interior barrier (plates 1 and 2). The generalized lithologic $\log$, shown on the left of figure 3, was obtained from 12 auger spin samples and 5 split-spoon samples (collected at depths of approximately $61,64,73,94$, and $100 \mathrm{ft}$ below land surface). The observed relative resistance of drilled subsurface materials is shown in the middle of figure 3 and delineated in red where resistive "hard to drill" layers were encountered. These resistive layers generally correspond to the cobble units $(\mathrm{C} 1$, $\mathrm{C} 2$, and $\mathrm{C} 3$ ). The hydrostratigraphic units (table 2), shown second from left in figure 3 , are based on the natural gammaray log as well as the lithology, resistance of drilled layers, and the EM conductance log.

The natural gamma-ray log shows that counts vary from 105 to 65 counts per second (cps) (fig. 3). Gamma-ray counts exceeding 85 cps generally correspond to cobble units $(\mathrm{C} 1$, $\mathrm{C} 2, \mathrm{C} 3$ ), till, and some "dirty" (with fines) detritus gravel layers (IS1). The cobble units are poorly sorted, ranging in grain size from silt to cobbles. The cobble clasts are supported 
Table 2. Hydrostratigraphic codes, unit names, and description, OU1 area, Savage Superfund site, Milford, New Hampshire.

\begin{tabular}{|c|c|c|}
\hline Code & Unit name & Description of hydrostratigraphic units \\
\hline $\mathrm{S}$ & Topsoil & Topsoil, in some places penetrated bentonite cap. \\
\hline $\mathrm{C} 1$ & Uppermost cobble layer & $\begin{array}{l}\text { Uppermost cobble layer; large cobbles to fine sand matrix, can have sand lenses within; } \\
\text { generally poorly sorted. }\end{array}$ \\
\hline US1 & Uppermost gravel and sand layer & Gravel and sand layer; well sorted. \\
\hline $\mathrm{C} 2$ & Middle cobble layer 2 & $\begin{array}{l}\text { Can contain cobbles but in some locations primarily sand and gravel, more permeable } \\
\text { than } \mathrm{C} 3 \text {. }\end{array}$ \\
\hline MS1 & Middle sand layer 1 & Coarse sand (0.5) to fine gravel, pebbles; trace medium sand (1.5). \\
\hline IS1 & $\begin{array}{l}\text { Interbedded sand, gravel, and } \\
\text { cobbles }\end{array}$ & Some cobbles and gravel, variable matrix material. \\
\hline VFS & Very fine sand layer & Very fine sand unit, limited spatially. \\
\hline MS2 & Middle sand layer 2 & Primarily a well-sorted sand layer $(\mathrm{m}-\mathrm{c})$, some fine sand and some fine gravel. \\
\hline BS1 & Basal sand & Sand layer, less permeable than the unit above. \\
\hline UPPER TILL & Upper till & $\begin{array}{l}\text { Identified in lithologic logs as a poorly sorted fine to coarse sand and gravel with trace } \\
\text { amounts of silt or clay; gray to brown. Limited spatially. }\end{array}$ \\
\hline TILL & Basal till & $\begin{array}{l}\text { Poorly sorted basal till except in western part of OU1 where it is thicker with some sand } \\
\text { lenses; olive green. }\end{array}$ \\
\hline WX & Weathered rock & Identified in lithologic logs as weathered bedrock. Limited spatially. \\
\hline BEDROCK & Bedrock & Indurated competent bedrock. \\
\hline
\end{tabular}

within a fine-grained matrix. Gamma-ray counts less than 85 cps correspond to clean, well-sorted sands and gravels.

The EM log from PW-20D shows several sharp inflections "spikes" (high anomalous readings above 15 millisiemens per meter $(\mathrm{mS} / \mathrm{m}))$, which are likely the results of metal in the hole from drilling. The metal corresponds to the competent, hard, resistive units that cause the metal flakes from the augers to break off. EM spikes from metal occur at depths of 8 and $54 \mathrm{ft}$. Other high EM readings at 24- and 28-ft depths correspond to relatively low gamma-ray counts and indicate electrically conductive groundwater is present in a permeable, clean, sandy unit (US1).

The cobble units $(\mathrm{C} 1, \mathrm{C} 2$, and $\mathrm{C} 3)$ and IS1 unit correlate over much of the OU1 site from the INEEL test area in figure 2, and appear as semi-planar features at similar altitudes. They appear to represent glaciodeltaic topset or glaciofluvial deposits. Kostic and others (2005) found that ice-marginal glaciodeltaic topset deposits in Germany contained significant amounts of fine-grained sediments within the matrix of a pebble-cobble clast. This type of lithology is indicative of rapid deposition. The altitude of the base of the C1 unit (260 ft above NGVD 29) corresponds to the altitude of a former glacial melt-water spillway located in downtown Milford, New Hampshire (Koteff, 1970), and, thus, likely represents a topset deltaic deposit.

The lowermost sandy units, BS1 and LS1, appear to represent delta bottomset (BS1) and foreset (LS1) beds that coarsen upward, as indicated by a decrease in gamma-ray counts, from the base of BS1 to the top of LS1 (below C3; fig. 3). Unit BS1 is discontinuous, deposited in deep bedrock troughs, and present in 25 out of 39 test holes at OU1 (table 3).

The upper sand units (US1, MS1, and MS2) likely represent glacial deposition from cyclic glacial progression and regression where proximal to distal sediments are deposited. All sandy units contain some gravel; however, the lowermost basal sand unit (BS1) contains the least gravel. The sandy units are typically thicker than the cobble units (table 3).

The lowermost overburden unit, the till, mantles the bedrock surface. The till is discontinuous but is identifiable at 22 out of 39 test holes at OU1 (table 3). Thick till deposits, associated with an upper till deposit, have been noted in drilling logs from the western part of OU1, along the western edge of the barrier. 

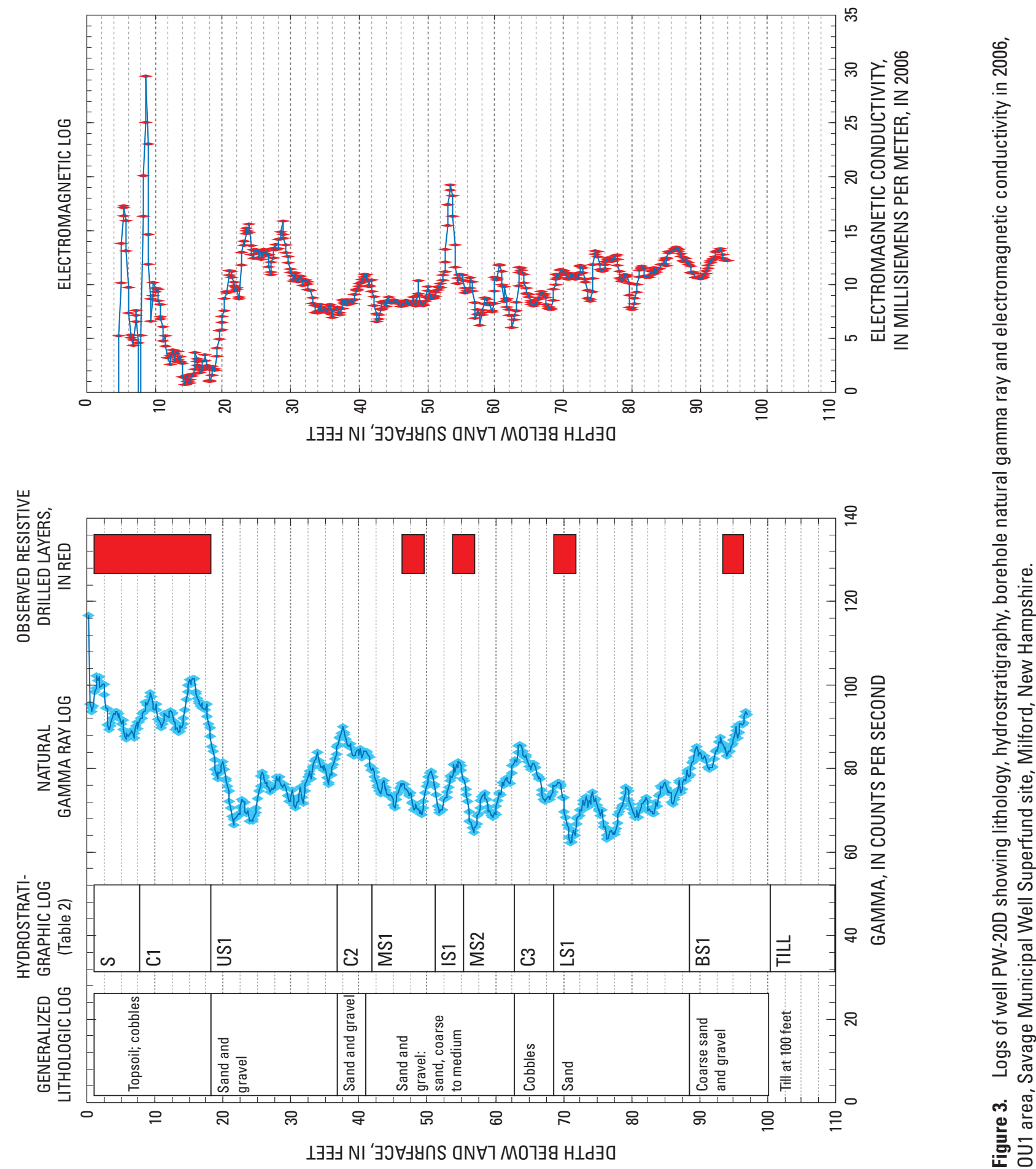
Table 3. Summary of unconsolidated hydrostratigraphic units and thickness, OU1 area, Savage Superfund site, Milford, New Hampshire.

[--, no estimate; yellow shading indicates sandy layers]

\begin{tabular}{lcccc}
\hline \multirow{2}{*}{ Units } & $\begin{array}{c}\text { Number } \\
\text { of holes } \\
\text { detected }\end{array}$ & \multicolumn{3}{c}{$\begin{array}{c}\text { Thickness, } \\
\text { in feet }\end{array}$} \\
\cline { 3 - 5 } & 36 & 6.0 & 10 & Average \\
Maximum & Minimum \\
\hline C1 & 39 & 10.7 & 22 & 4 \\
US1 & 38 & 16.1 & 23 & 8 \\
C2 & 35 & 5.2 & 15 & 0 \\
MS1 & 36 & 9.8 & 25 & 0 \\
IS1 & 35 & 6.9 & 21 & 0 \\
MS2 & 34 & 7.8 & 18 & 0 \\
VFS & 1 & 112 & -- & -- \\
C3 & 32 & 4.0 & 12 & 0 \\
LS1 & 30 & 8.3 & 26 & 0 \\
BS1 & 25 & 3.4 & 22 & 0 \\
UPPER TILL & 1 & 121 & -- & -- \\
TILL & 22 & 4.6 & 36.5 & 0 \\
WX & 1 & 12 & -- & -- \\
\hline
\end{tabular}

${ }^{1}$ Individual sample.

\section{Gamma and Radioisotope Characteristics}

Concentrations of $\mathrm{K}, \mathrm{U}$, and $\mathrm{TH}$ elements in lithologic (sediment) samples of test holes, as determined from gammaray spectrometry measurements, were compared to borehole gamma-ray counts from borehole logging for coincident depths and locations. The spectrometry concentration for $\mathrm{TH}$ weakly to moderately correlates to the borehole gamma-ray count $\left(\mathrm{R}^{2}=.346, p\right.$-value 0.003 ; table 4$)$. A graphical plot of TH concentrations and associated borehole gamma-ray count is shown in figure 4, as grouped by hydrostratigraphic unit. In contrast, $\mathrm{K}$ and $\mathrm{U}$ concentrations correlated poorly to borehole gamma-ray counts (table 4).

Samples were grouped by hydrostratigraphic units, and mean concentrations for $\mathrm{K}, \mathrm{U}$, and $\mathrm{TH}$ were computed to identify bulk variation in element concentrations between units. Using this approach, variations were noted. The percentage of $\mathrm{K}$ in the sample, of which the radioisotope element K-40 represents 0.012 percent (Keys, 1990), ranged from 1.71 (units MS2) to 2.53 (unit C3) with a mean from all samples of 2.28 . The concentration of $\mathrm{U}$ ranged from 1.81 parts per million (ppm) (unit MS2) to $2.83 \mathrm{ppm}$ (unit C1) with a mean from all samples of $2.44 \mathrm{ppm}$. The concentration of Th ranged from $6.92 \mathrm{ppm}$ (unit MS2) to $18.33 \mathrm{ppm}$ (unit Till) with a mean for
Table 4. Coefficients of determination and significance for correlation of radioactive element concentration and associated borehole natural gamma-ray count, OU1 area, Savage Superfund site, Milford, New Hampshire.

$\left[\mathrm{R}^{2}=\right.$ coefficient of determination; $p$-value $=$ significance at 95 -percent confidence level; $\mathrm{K}=$ potassium; $\mathrm{U}=$ uranium; $\mathrm{TH}=$ thorium. $\mathrm{R}^{2}$ is a statistic that gives information about the goodness of fit of a model. In regression, the $\mathrm{R}^{2}$ coefficient of determination is a statistical measure of how well the regression line approximates the real data points. An $\mathrm{R}^{2}$ of 1.0 indicates that the regression line perfectly fits the data. The $p$-value is the probability that the current result would occur if the coefficient of determination were in fact zero (null hypothesis). If this probability is lower than the conventional 5 percent $(p<0.05)$, the correlation coefficient is called statistically significant]

\begin{tabular}{cccc}
\hline Element & $\mathbf{R}^{2}$ & $\boldsymbol{p}$-value & Comment \\
\hline $\mathrm{K}$ & 0.048 & 0.317 & \\
$\mathrm{U}$ & 0.104 & 0.133 & \\
$\mathrm{TH}$ & 0.346 & 0.003 & $\begin{array}{c}\text { Significant at the 0.05 confi- } \\
\text { dence interval; comparison } \\
\text { shown in figure 4. }\end{array}$ \\
\hline
\end{tabular}

all samples of $11.22 \mathrm{ppm}$. Thus, the lowest element values for $\mathrm{K}, \mathrm{U}$, and TH were identified in unit MS2, whereas the highest element values were identified in the cobble layers $(\mathrm{C} 1$ and C3) and the till.

Thorium concentrations show greater variability per hydrostratigraphic unit than $\mathrm{K}$ or $\mathrm{U}$ (table 5). The till and unit $\mathrm{C} 1$ (uppermost cobble layer) have the highest gamma-ray counts and highest measured Th concentration. The sand units (MS2 and US1) have the lowest gamma-ray counts and lowest measured thorium concentration. Thus, the variability in Th concentration appears to contribute to some variability in borehole natural gamma-ray counts.

\section{Hydraulic Characteristics}

Hydraulic conductivity estimates based on methods described by Olney (1983) of grain-size analysis compared favorably to estimates from slug tests at the site, considering differences in sample volume that each method uses (appendix 1). Hydraulic conductivity estimates based on grain-size analysis represent a non-directional measurement of a spherical volume several inches in diameter. Hydraulic conductivity estimates based on slug tests likely represent horizontal measurements of the most permeable layers within the screen length (typically $10-\mathrm{ft}$ long) of the well. Given the sample volume differences ${ }^{1}$, hydraulic conductivity estimates from grain-size analysis were deemed reasonable in characterizing the variations of hydraulic conductivity per hydrostratigraphic unit.

\footnotetext{
${ }^{1}$ The affected volume of a slug test in a $10-\mathrm{ft}$ long well is likely 100 times greater than that of a grain-size analysis.
} 


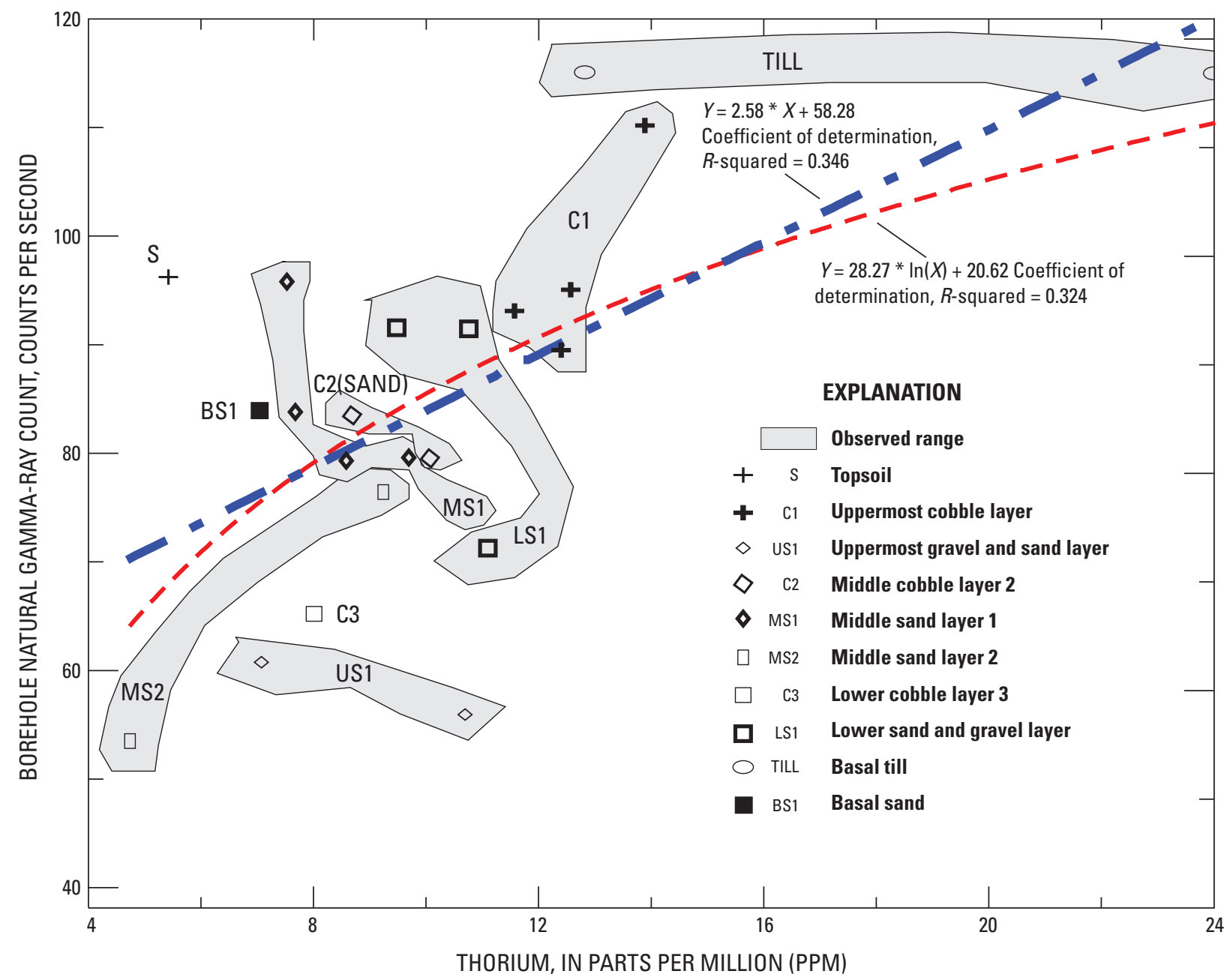

Figure 4. Plot of borehole natural gamma-ray counts to corresponding thorium concentration per hydrostratigraphic unit, OU1 area, Savage Municipal Well Superfund site, Milford, New Hampshire.

Results of the grain-size analysis show that the most permeable units are the sandy units: US1, MS1, and LS1 (table 6). A maximum hydraulic conductivity of $1,479 \mathrm{ft} / \mathrm{d}$ was estimated in grain-size samples derived from the lower sand unit. The cobble units $(\mathrm{C} 1, \mathrm{C} 2$, and $\mathrm{C} 3)$ and unit IS1 generally are less permeable given their poorer degree of sorting than the sandy units, although small-scale, more permeable, sandy lenses can be present within the cobble units and unit IS1. A minimum hydraulic conductivity of $8 \mathrm{ft} / \mathrm{d}$ was estimated in grain-size samples derived from unit $\mathrm{C} 3$ and the till.

Several units (such as IS1) have no hydraulic conductivity estimates and several more units (C3, BS1, and Till) have an estimate from only one grain-size sample. To augment the quantification of hydraulic conductivity per unit, single-well, hydraulic-test data (Camp, Dresser, and McKee,
Inc., 1996) were used as a means of comparing variations in hydrostratigraphic units.

For the 15 observation wells with hydraulic test data, screens in four wells are set in one hydrostratigraphic unit, whereas screens in the remaining 11 wells cross multiple hydrostratigraphic units. Of the four wells, two are screened in the IS1 unit with a hydraulic conductivity estimate of 46 and $88 \mathrm{ft} / \mathrm{d}$, one is screened in the MS2 unit with a hydraulic conductivity estimate of $272 \mathrm{ft} / \mathrm{d}$, and one is screened in the LS1 unit with a hydraulic conductivity estimate of $300 \mathrm{ft} / \mathrm{d}$. For the LS1 unit, the hydraulic conductivity estimates from the hydraulic well test and the grain-size methods compare favorably and indicate a relatively highly permeable unit. For the MS2 unit, the hydraulic well test indicates a more permeable unit than is indicated by the grain-size method. 
Table 5. Mean concentration of analyzed radioactive elements for selected hydrostratigraphic units, OU1 area, Savage

Superfund site, Milford, New Hampshire.

$[\mathrm{K}=$ potassium; $\mathrm{U}=$ uranium; $\mathrm{TH}=$ thorium; $\mathrm{ppm}=$ parts per million $]$

\begin{tabular}{lcccc}
\hline Unit & $\begin{array}{c}\text { Number of } \\
\text { samples from } \\
\text { sediments } \\
\text { collected in } \\
\text { 2006-08 }\end{array}$ & $\begin{array}{c}\text { K } \\
\text { (percent) }\end{array}$ & $\begin{array}{c}\text { Mean } \\
\text { (ppm) }\end{array}$ & $\begin{array}{c}\text { TH } \\
\text { (ppm) }\end{array}$ \\
\hline ALL & 25 & 2.28 & 2.44 & 11.22 \\
\hline C1 & 5 & 2.43 & 2.83 & 11.41 \\
\hline C2 & 2 & 2.21 & 2.48 & 9.29 \\
\hline C3 & 3 & 2.53 & 2.52 & 16.66 \\
\hline LS1 & 4 & 2.14 & 2.61 & 11.49 \\
\hline MS1 & 5 & 2.44 & 2.26 & 8.80 \\
\hline MS2 & 2 & 1.70 & 1.81 & 6.92 \\
\hline TILL & 2 & 2.53 & 2.71 & 18.33 \\
\hline US1 & 2 & 2.34 & 2.27 & 8.79 \\
\hline
\end{tabular}

\section{Discussion of Hydrostratigraphic Units}

The analysis of radioactive-element concentrations, hydraulic conductivity, and borehole natural gamma-ray logs indicates that the designated hydrostratigraphic units show a combination of lithologic, mineralogic (as a function of radioactive element concentrations for $\mathrm{K}, \mathrm{TH}$, and $\mathrm{U}$ ), and permeability variations. There is a weak-to-moderate relation between the radioisotope concentrations (thorium) and borehole natural gamma-ray count. Furthermore, on the basis of grain-size analysis, there is a general relation between lower hydraulic conductivity estimates derived from grain size and the corresponding higher radioactive element concentration or borehole gamma-ray count. A relative ranking of radioisotope element concentrations (ordered low to high), borehole gamma-ray counts (ordered low to high), and hydraulic conductivity estimates (ordered high to low) is provided in table 7. The till unit shows high borehole gamma-ray counts, high radioactive element concentrations, and low hydraulic conductivity. In contrast, unit US1 shows low borehole gamma-ray counts, low radioactive element concentrations, and high hydraulic conductivity. Several exceptions to these observations exist, and low radioactive element concentrations and borehole gamma-ray counts do not always relate to higher
Table 6. Estimates of hydraulic conductivity from effective grain size (D90) for selected hydrostratigraphic units, OU1 area, Savage Superfund site, Milford, New Hampshire.

[--, no data; D90 is the effective grain size at 90-percent coarser size; data were obtained using the D90 method by Olney (1983); measured hydraulic conductivity is non-directional]

\begin{tabular}{|c|c|c|c|c|c|}
\hline \multirow[t]{2}{*}{ Unit } & \multirow{2}{*}{$\begin{array}{c}\text { Num- } \\
\text { ber of } \\
\text { samples }\end{array}$} & \multicolumn{3}{|c|}{$\begin{array}{c}\text { Hydraulic conductivity, } \\
\text { feet/day }\end{array}$} & \multirow[t]{2}{*}{ Comment } \\
\hline & & Mean & Minimum & Maximum & \\
\hline $\mathrm{S}$ & 0 & -- & -- & -- & \\
\hline $\mathrm{C} 1$ & 2 & 18.5 & 5 & 32 & \\
\hline US1 & 3 & 51.8 & 27 & 141 & \\
\hline $\mathrm{C} 2$ & 2 & 15.5 & 13 & 18 & \\
\hline MS1 & 5 & 54.2 & 10 & 168 & \\
\hline IS1 & 0 & -- & -- & -- & \\
\hline MS2 & 2 & 11.5 & 8 & 15 & \\
\hline $\mathrm{C} 3$ & 1 & ${ }^{18}$ & -- & -- & One sample. \\
\hline LS1 & 6 & 296 & 5 & 1,479 & \\
\hline $\mathrm{BS} 1$ & 1 & 139 & -- & -- & One sample. \\
\hline TILL & 1 & ${ }^{1} 8$ & -- & -- & One sample. \\
\hline
\end{tabular}

hydraulic conductivities. LS1 and MS2 are examples of units with low borehole gamma-ray counts that do not correspond to high hydraulic conductivity. Unit LS1 has a high hydraulic conductivity but relatively high TH concentration and gammaray count, and unit ${ }^{2} \mathrm{MS} 2$ has a low hydraulic conductivity for the grain-size method but low radioactive element concentration and low borehole gamma-ray count.

Additional hydraulic conductivity measurements may prove useful to understanding the relations discussed here. Specifically, semi-continuous hydraulic-conductivity profiles within the barrier area would prove useful in mapping hydrostratigraphic units. In addition, improvements to the interpretation relating borehole gamma-ray counts to radioactive element concentration and hydraulic conductivity can be achieved if volumetric (bed thickness) adjustments are made to adjust the borehole gamma-ray count per the thickness of each unit. Bed thickness affects borehole natural gamma-ray counts because of the variation in the amount of natural gamma-ray source material. By re-computing borehole gamma-ray counts to account for bed thicknesses of the corresponding units for the comparison, rather than

\footnotetext{
${ }^{2}$ For the MS2 unit, the results of the hydraulic well test indicated a more permeable unit than was indicated by the grain-size method.
} 
Table 7. Relative ranking of radioactive elements based on concentration, hydraulic conductivities, and borehole natural gamma-ray counts for selected hydrostratigraphic units, OU1 area, Savage Superfund site, Milford, New Hampshire.

$[\mathrm{K}=$ potassium; $\mathrm{U}=$ uranium; $\mathrm{TH}=$ thorium; --, no data; blue shading indicates high relative concentration ranking $]$

\begin{tabular}{|c|c|c|c|c|c|}
\hline \multirow{3}{*}{$\begin{array}{c}\text { Hydrostratigraphic } \\
\text { units }\end{array}$} & \multirow{2}{*}{\multicolumn{3}{|c|}{$\begin{array}{l}\text { Concentration } \\
\text { Relative ranking } \\
\text { (low to high) }\end{array}$}} & \multirow{3}{*}{$\begin{array}{c}\text { Relative ranking } \\
\text { (low to high) }\end{array}$} & \multirow{3}{*}{$\begin{array}{c}\begin{array}{c}\text { Relative ranking } \\
\text { (high to low) }\end{array} \\
\text { Hydraulic conductivity estimate } \\
\text { (1 = high) }\end{array}$} \\
\hline & & & & & \\
\hline & $\begin{array}{c}K \\
(1=\text { low })\end{array}$ & $\begin{array}{c}U \\
(1=\text { low })\end{array}$ & $\begin{array}{c}\text { TH } \\
(1=\text { low })\end{array}$ & & \\
\hline $\mathrm{C} 1$ & 5 & 8 & 5 & 7 & 4 \\
\hline $\mathrm{C} 2$ & 3 & 4 & 4 & 4 & 5 \\
\hline $\mathrm{C} 3$ & 8 & 5 & 7 & 3 & 7 \\
\hline LS1 & 2 & 6 & 6 & 6 & 1 \\
\hline MS1 & 6 & 2 & 3 & 5 & 2 \\
\hline MS2 & 1 & 1 & 1 & 2 & 6 \\
\hline TILL & 7 & 7 & 8 & 8 & 8 \\
\hline US1 & 4 & 3 & 2 & 1 & 3 \\
\hline BS1 & -- & -- & -- & -- & -- \\
\hline
\end{tabular}

using the point measurements of borehole gamma-ray counts associated with the unit themselves, a more representative borehole gamma-ray count per hydrostratigraphic unit could be determined.

\section{Hydrostratigraphic Surface Maps}

Contours of altitudes of the bedrock surface (fig. 5) and till surface (fig. 6) are shown with data points used in the surface interpolation process. For the bedrock surface, in addition to well and boring information, confirmed bedrock depths from trenching of the barrier were used as a control and appear in a footprint oval pattern (fig. 5).

The bedrock surface varies from an altitude of 160 to $215 \mathrm{ft}$ (NGVD 29) and slopes to the east. The greatest depth to bedrock occurs at a boring near the southeast area of the barrier. A deep bedrock trough runs from B95-1 to the northeast through PW-5R, PW-2R, up toward PW-11D, and toward MW-2R (across the river; fig. 5). A bedrock saddle is present near EW-2 (fig. 5). The bedrock surface is shallower to the west where a north-south trending bedrock knob underlies the INEEL field area. Along the western part of the barrier, the bedrock surface is about 8 to $10 \mathrm{ft}$ deeper than near the INEEL field but slopes upward to the west from that location.
The altitude of the top of basal till surface (fig. 6), which generally overlies the bedrock surface, follows a pattern similar to that of the top of bedrock surface, except where the till thickness increases near well PW-19D and near IW-1. At these two locations the till thickness increases from an average thickness of several feet to more than $10 \mathrm{ft}$ (fig. 7). At PW-19D, till thickness is inferred, in part, from encountering refusal during auger drilling.

A basal till thickness map shows that till overlies most of the OU1 area except for several areas near PW-5R, PW-2R, PW-12R, and by EW-2 (figs. 2 and 7). Till thicknesses exceed $10 \mathrm{ft}$ near IW-1, IW-2, MI-22, and by MW-2R where thicknesses exceed $35 \mathrm{ft}$.

The altitude of the bottom surface of hydrostratigraphic unit MS2 (structure contour map; fig. 8) shows that there is a slight dip of $0.04 \mathrm{ft} / \mathrm{ft}$ to the east. This map can be used to help track lateral solute transport of PCE from source areas in the western part of interior barrier area, given that high PCE concentrations have been observed within the sandy units of the site (Harte, 2008) and PCE concentrations exceeding $500 \mu \mathrm{g} / \mathrm{L}$ have been measured in several wells (PW-15D, PW-16D) screened across the MS2 unit. 


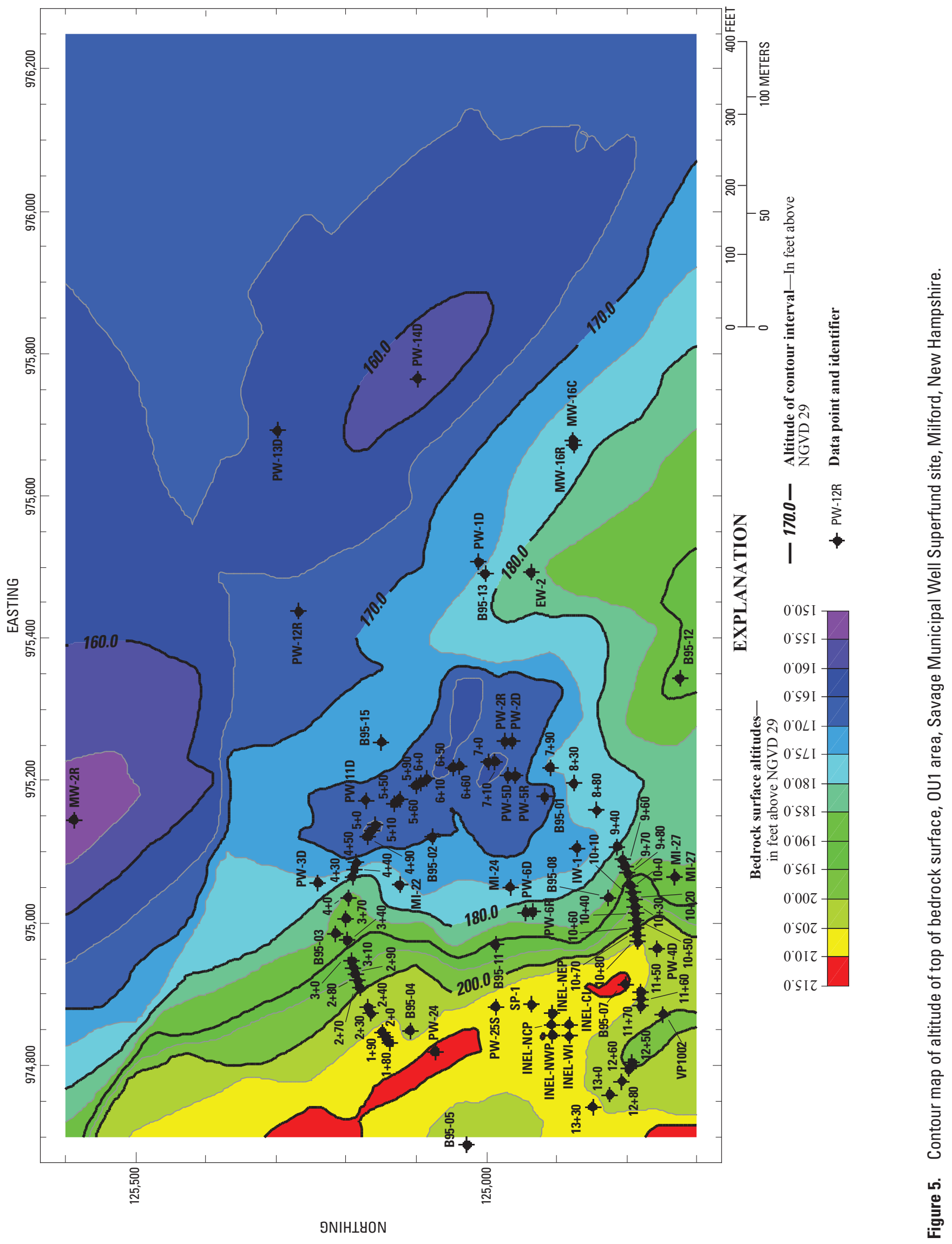




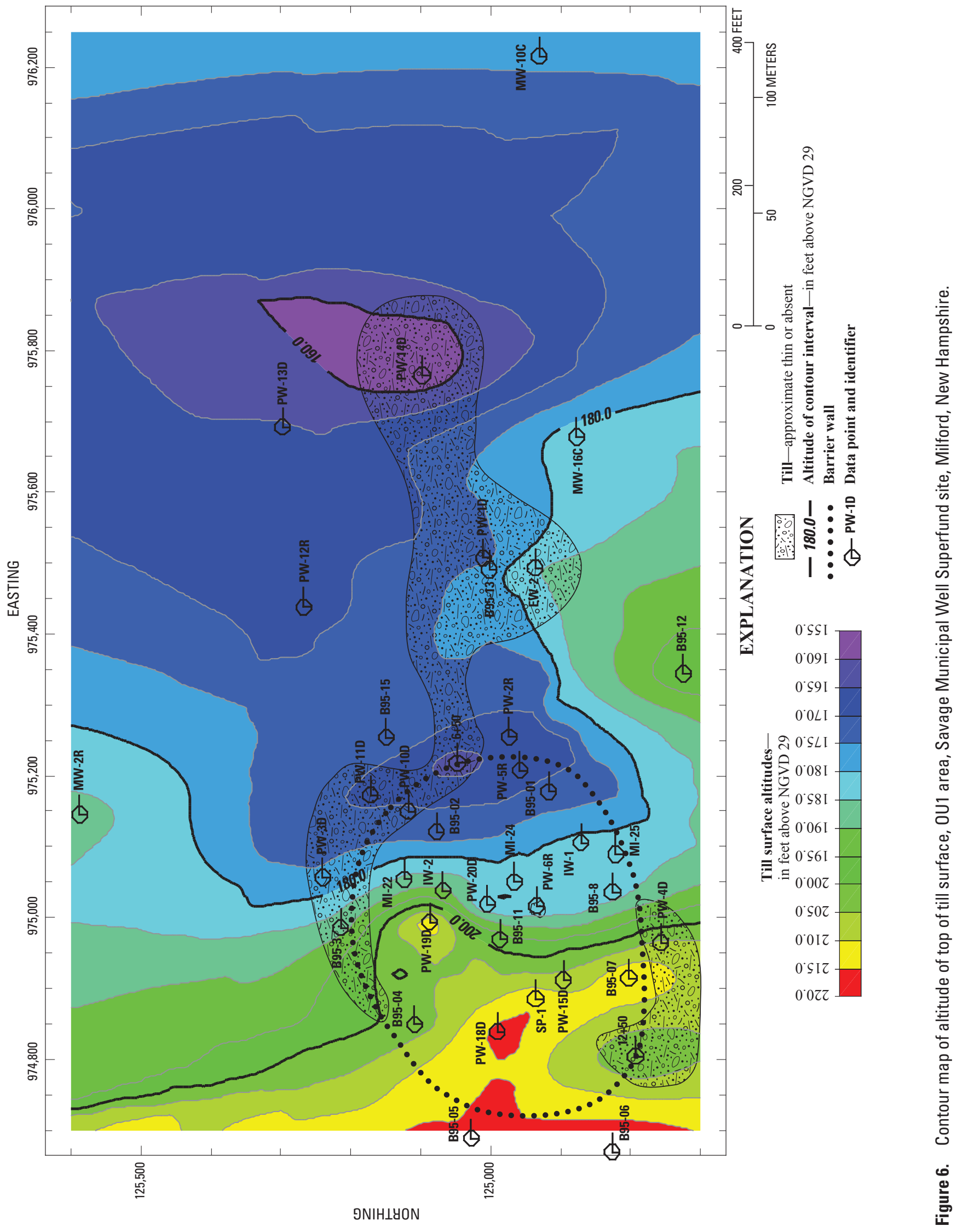




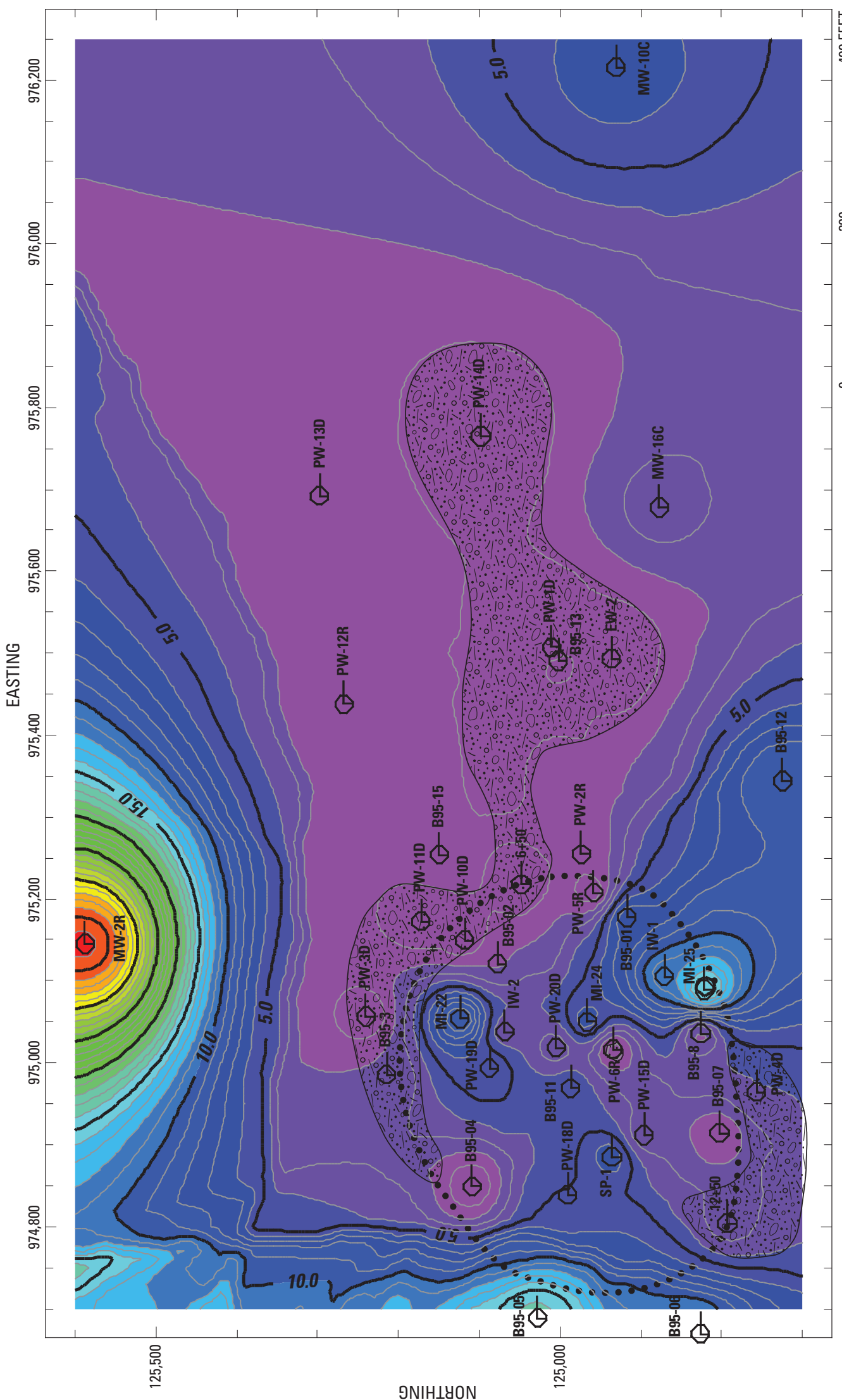

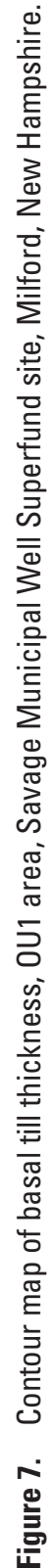




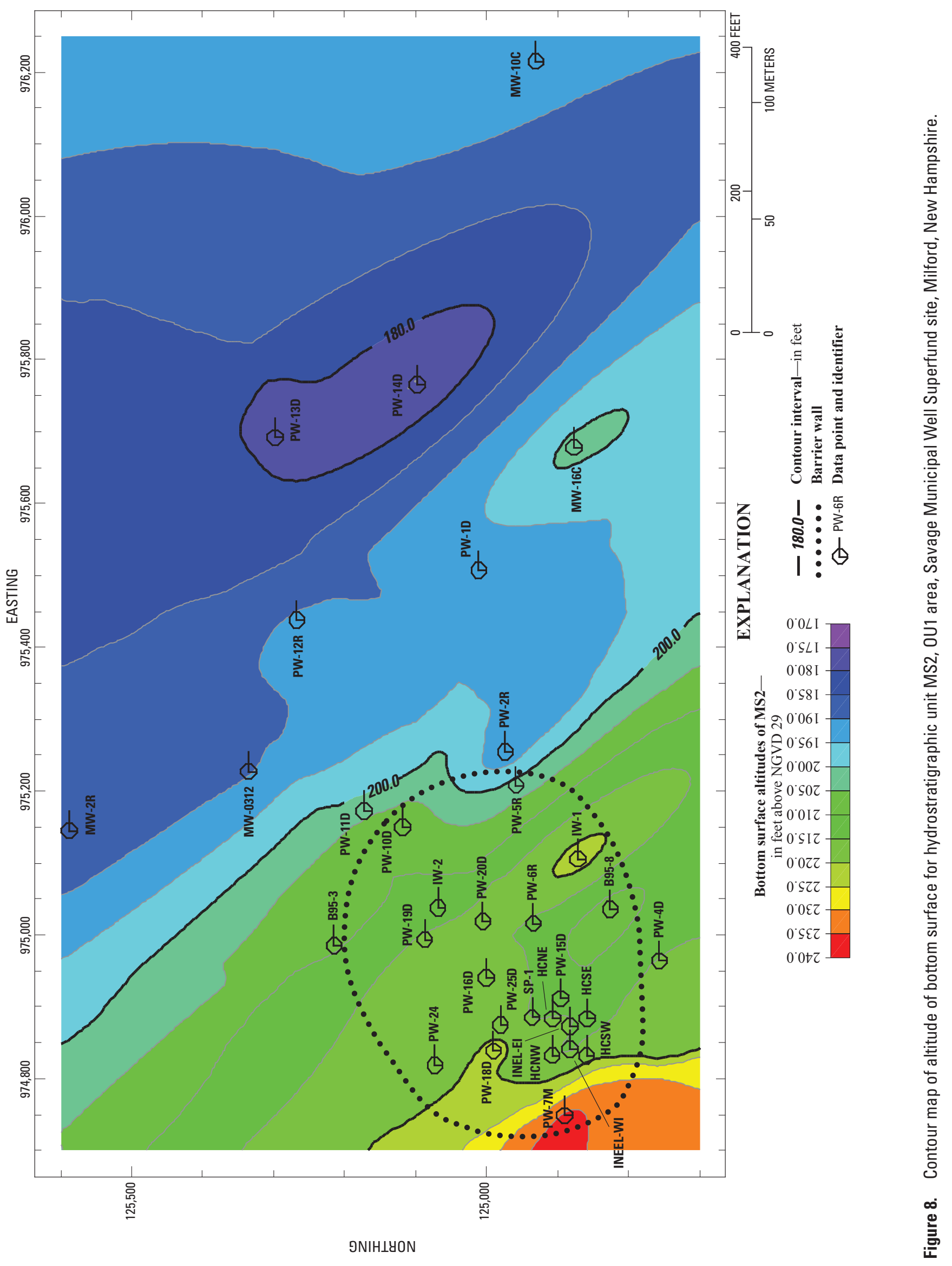




\section{Hydrostratigraphic Sections}

A transverse cross-section A-A' (shown in fig. 2), trending north to south through the interior barrier wall area of OU1, from well B95-3 to PW-4D, is shown in figure 9. Spatial variations of lithology based on lithologic logs are difficult to discern because of differences in drilling and lithologic sampling at each borehole/well. For example, the presence of cobbles within $20 \mathrm{ft}$ of land surface were noted on driller's logs for the wells located on the transverse cross-section A-A' installed in 1995 (wells labeled with the letter "B") and wells installed during 2006-07 [well labeled PW-6MB and wells labeled PW-15 and above (higher numbers)]. However, cobbles were absent in the upper $20 \mathrm{ft}$ for wells installed during 1998-99 (wells labeled PW-14 and less). Good examples of this are logs from wells PW-6R (no shallow depth cobbles noted; plate 1a) and PW-6MB (shallow depth cobbles listed in log; plate 1b). Given the proximity of PW-6MB and PW-6R, and the presence of cobbles in logs on either side of the log for $\mathrm{PW}-6 \mathrm{R}$, it is likely that cobbles from $\mathrm{C} 1$ unit are contiguous throughout this section.

Fine sand layers are noted on B95-3 log at 245-ft altitude and at the 200-ft altitude, whereas they are absent elsewhere, except at B95-8 at the 190-ft altitude. Well-sorted sandy layers are present above and below the $230-\mathrm{ft}$ altitude. Sand and gravel, and gravel and sand layers are present over most of the section. A thin basal till layer (about $5 \mathrm{ft}$ thick) is noted on most logs, except for that of PW-6R well.

Spatial variations in gamma-ray counts suggest vertical and horizontal spatial trends in lithology (fig. 10). Interpolations of gamma-ray counts were made using the horizontal-bias method that favors interpolation of layered, stratified deposits (fig. 10). Low gamma-ray counts indicate the presence of clean well-sorted sands and gravels, whereas high gamma-ray counts indicate the presence of poorly sorted gravels, fine sands and silts, or large boulders and cobbles, which can emit relatively high radioactive gamma counts. The low counts (less than 90 counts per second (cps)) occurred in PW-19D east to PW-6 cluster in the middle-to-deep depths. Another low count zone occurred near PW-4D at an altitude below $230 \mathrm{ft}$. The presence of fine sands reported in driller logs for B95-3 and B95-8 (below 210-ft altitude) are supported by relatively high gamma-ray counts (greater than $120 \mathrm{cps}$ ) at these wells.

An interpreted stratigraphy for section $\mathrm{A}^{-\mathrm{A}^{\prime}}$ was generated based on interpretation of lithology, drilling resistance, and borehole geophysical natural gamma-ray and electromagnetic logs (fig. 11). The section shows that contiguous layers, denoted by yellow in figure 11, represent the more permeable sandy units. The non-yellow layers generally represent more poorly sorted materials, sometimes cobbles to fine-sand sediments; however, within those units more permeable lens can be present. Several of the less permeable units pinch out and are absent at certain locations (such as PW-19D and B95-3).

\section{Hydrostratigraphic Effects on Flow, Transport of PCE, and Remediation}

Stratigraphic controls have been shown to be a factor in distribution of recalcitrant PCE concentrations in OU1 (Harte, 2008). The distribution of the recalcitrant PCE layers was mapped vertically by analyzing borehole natural gammaray logs in conjunction with PCE concentrations. At several locations, recalcitrant PCE concentrations correlated with large changes in gamma-ray counts and changes in lithology, indicating the presence of stratigraphic contacts (Harte, 2008). The highest PCE concentrations occurred within well-sorted sands and gravels situated above relatively poorly sorted, less permeable sediments.

The occurrence of the highest PCE concentrations within the more permeable layers (near stratigraphic contacts) suggests that either a residual PCE source is located above the less permeable layers or residual PCE is vertically migrating into the permeable layers from the less permeable layers. A residual PCE source, such as a DNAPL source, adsorbed PCE on sediments, or high concentrations of dissolved PCE in pore water may be located near contacts because the original DNAPL source probably was located in this area because the low porosity or permeability layer initially retarded DNAPL movement. Therefore, remnant high dissolved PCE concentrations (above 10,000 $\mu \mathrm{g} / \mathrm{L}$ ) are present at that location. In the absence of a residual high PCE concentration or source zones, PCE concentrations in highly permeable layers would be lower than PCE concentrations in less permeable layers because of preferential transport and the differential flushing rates of cleaner, low PCE-concentration groundwater in high permeability layers.

The distribution of PCE concentrations in 2007 in wells along the A-A' transverse cross section (fig. 12) shows that highest PCE concentrations occur near the PW-6 well cluster (distance $300 \mathrm{ft}$ on fig. 12) and within the middle to lower hydrostratigraphic units (MS1, MS2, and LS1). High PCE concentrations also occur near the PW-20 cluster in the lower hydrostratigraphic unit (LS1 and BS1). The source area of PCE is upgradient to the west because groundwater flow is from the west to the east, toward the interior extraction wells (IW-1 and IW-2) from the INEEL well field and other potential source areas (by RW-1 and SP-2; fig. 2). The overall distribution of high PCE concentrations (greater than $1,000 \mu \mathrm{g} / \mathrm{L}$ ) relates to gamma-ray counts of less than $80 \mathrm{cps}$, indicating preferential transport in permeable zones (figs. 10 and 12). Within hydrostratigraphic units, heterogeneity in permeability is supported by variability in hydraulic conductivity measurements from grain-size analysis, slug tests, and borehole gamma-ray counts.

In 1996 (fig. 13), PCE concentrations were measured from vertical profiling of groundwater at 5 - $\mathrm{ft}$ intervals at several locations (plate 2) along the same section as shown in figure 12. The high-resolution sampling at that time allowed for a more comprehensive mapping of PCE concentrations, 

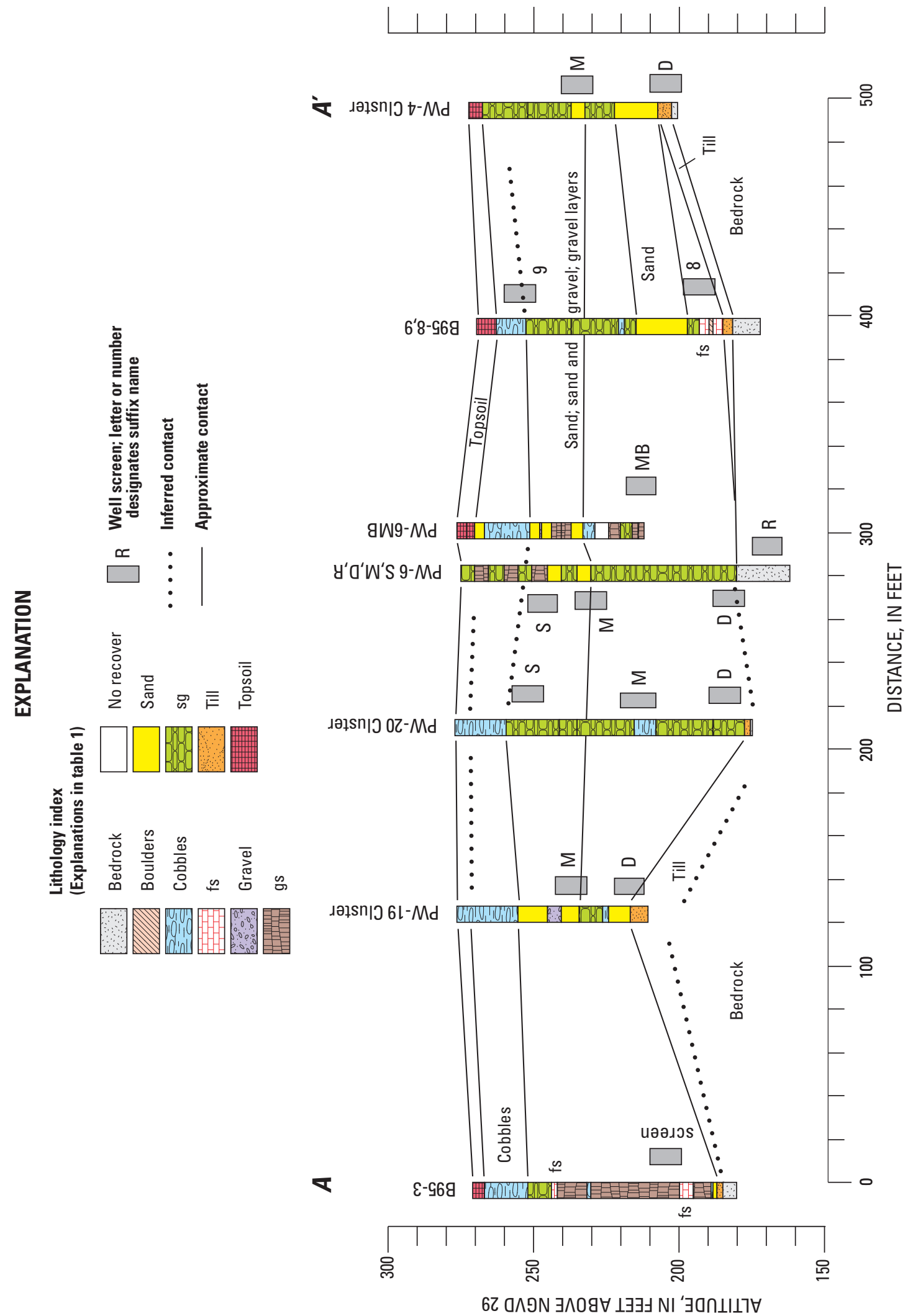

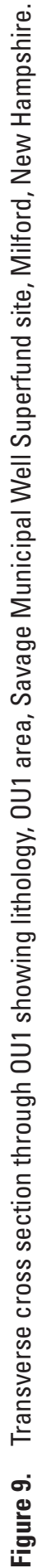




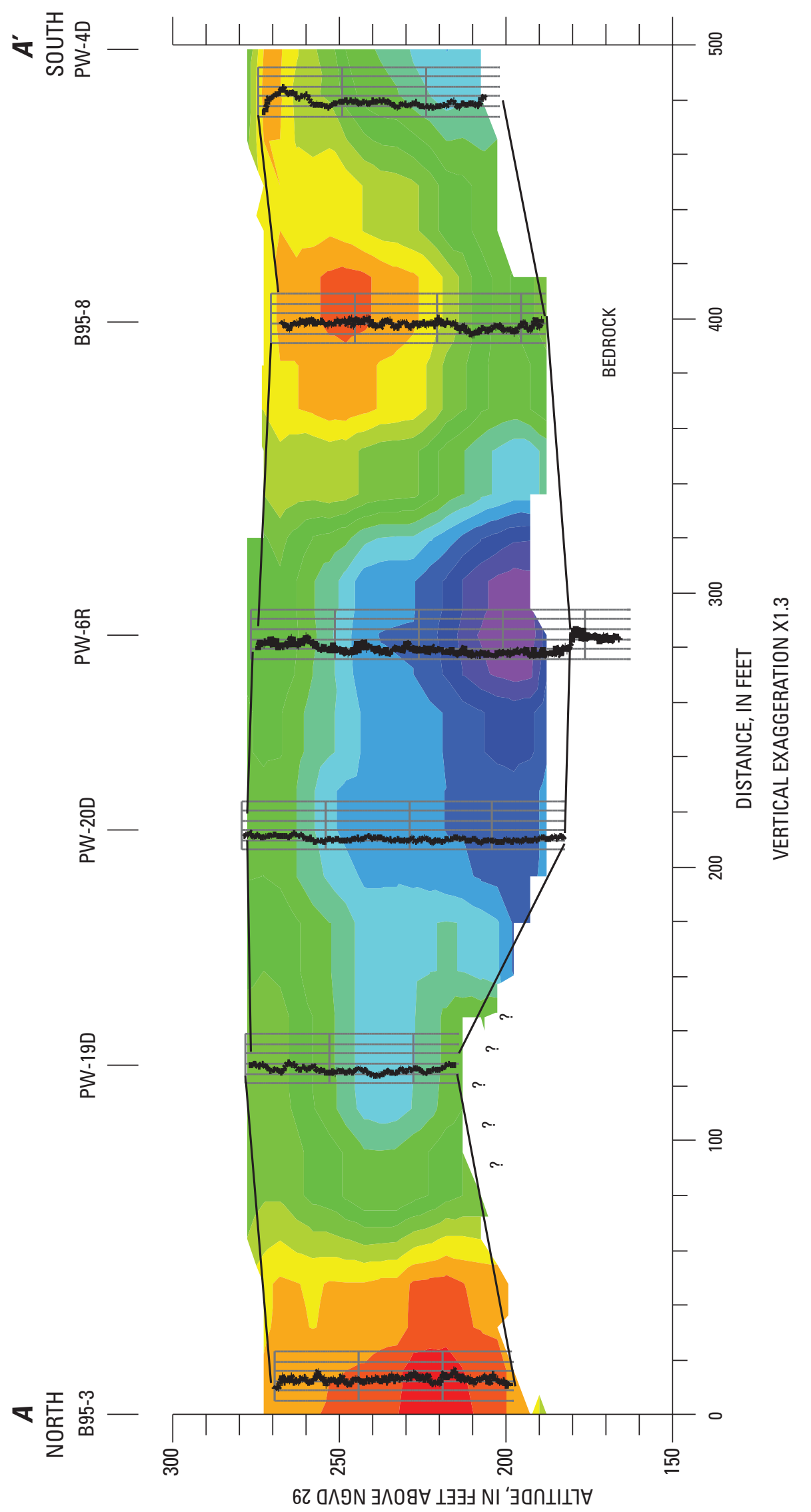




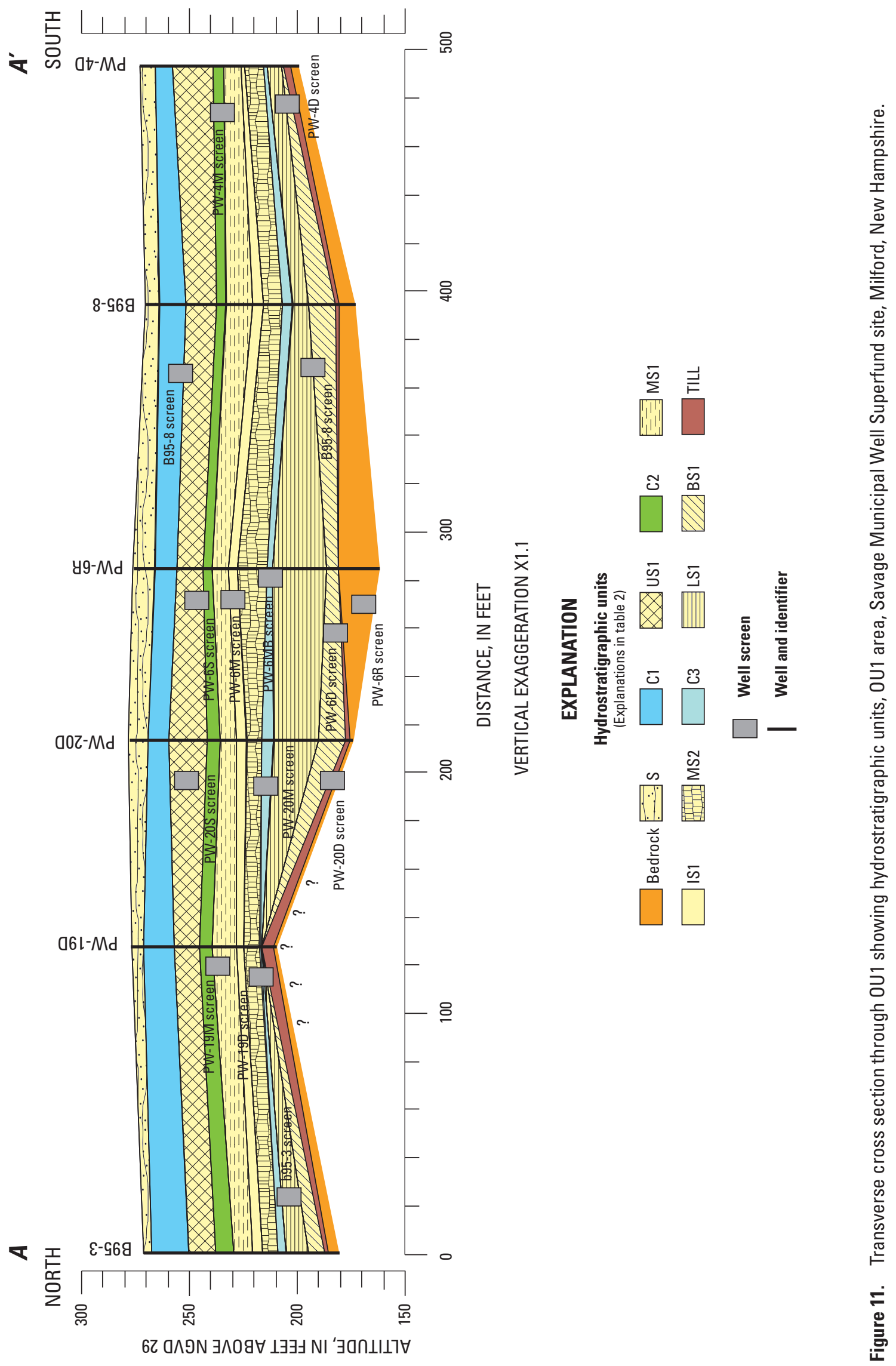




\section{Hydrostratigraphic Mapping of the Milford-Souhegan Glacial Drift Aquifer, and Transport of PCE, Savage Superfund Site}

which indicates the highest concentrations occurred in the middle to lower hydrostratigraphic units at an altitude of approximately $220 \mathrm{ft}$ above NGVD 29. At vertical profile location VP2007 (distance $330 \mathrm{ft}$ in fig. 13), the maximum PCE concentration occurred at the contact between IS1 and MS2. From hydrostratigraphic unit MS2 to C3 and C3 to LS1, a large decrease in concentrations occurred; this indicates that unit $\mathrm{C} 3$ retards vertical transport. At the abandoned pit area in the INEEL well field, a primary source area of contaminants upgradient (to the west) of VP2007 (plate 2; fig. 2), high PCE concentrations were mapped at similar altitudes in several profile points (Guilbeaut and others, 1997, 1998). This indicates PCE solute transport primarily moves laterally away from the pit area and likely within the semi-planar hydrostratigraphic units.

The distribution of the PCE plume in 1996 (preremediation) was wider and concentrations higher (greater than $6,000 \mu \mathrm{g} / \mathrm{L}$ ) than in 2007 (figs. 12 and 13). In 1996, PCE concentrations greater than $2,000 \mu \mathrm{g} / \mathrm{L}$ were present along almost the entire length of the section, whereas in 2007, the $2,000 \mu \mathrm{g} / \mathrm{L}$ concentrations were found in two areas near the PW-20 and PW-6 well clusters (fig. 12). Vertically, PCE concentrations in unit MS1 were relatively low (less than $1,000 \mu \mathrm{g} / \mathrm{L}$ ) in 2007 but were double that in 1996. In 2007, the plume appeared to be separating along the contact of unit IS1, indicating that vertical transport of PCE is restricted by that unit.

A comparison of PCE concentrations from an adjacent vertical profiling point (plate 2) with the borehole gamma log at PW-20D shows that the highest PCE concentrations occurred within the more permeable sandy units (low gammaray counts) and not the less permeable units with high gammaray counts (fig. 14). This supports the concept that solute transport moves primarily laterally within the sandy units. Furthermore, it suggests that residual high PCE concentrations (above 1,000 $\mu \mathrm{g} / \mathrm{L}$ ) are upgradient from this location, and PCE is transported within the more permeable layers. 


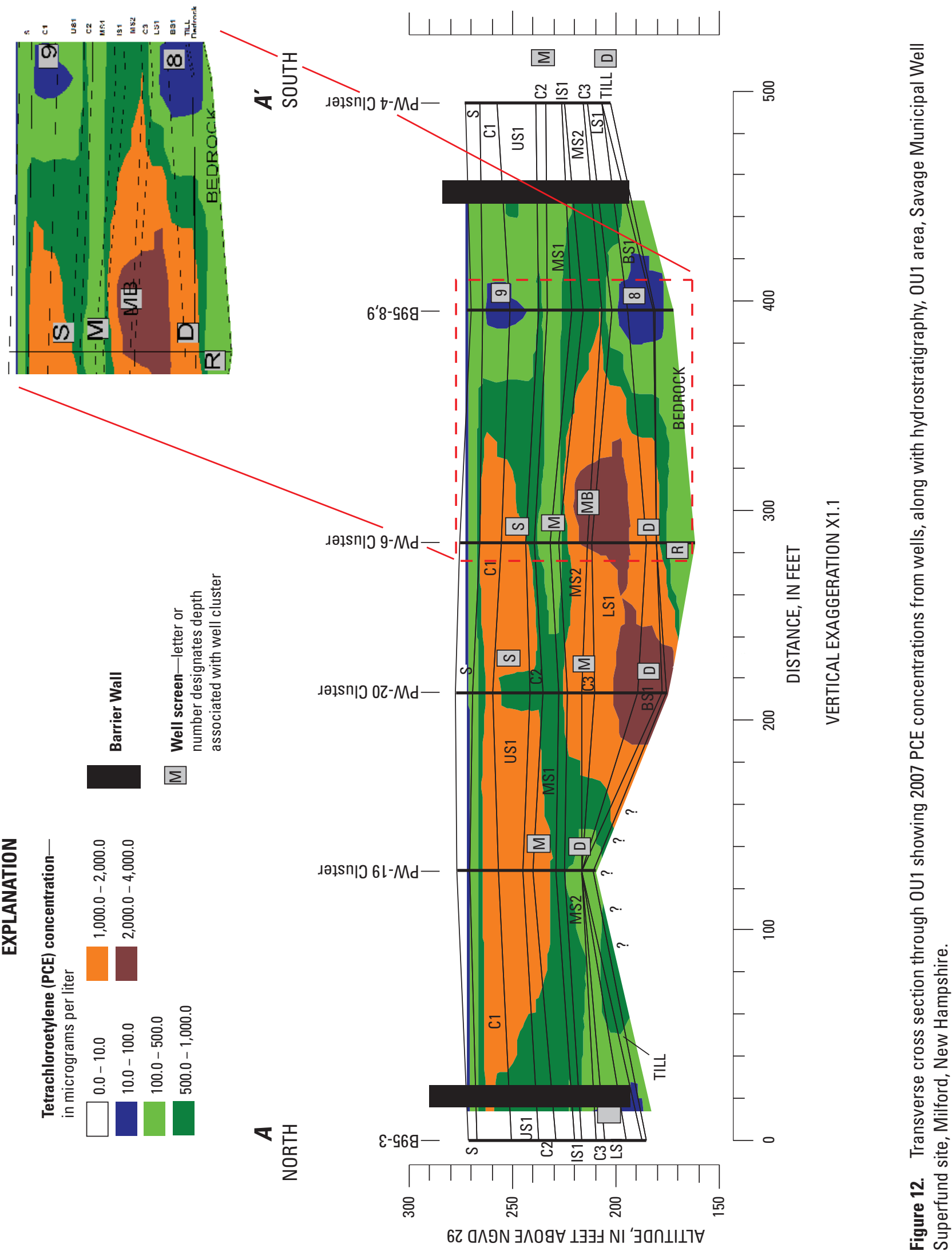




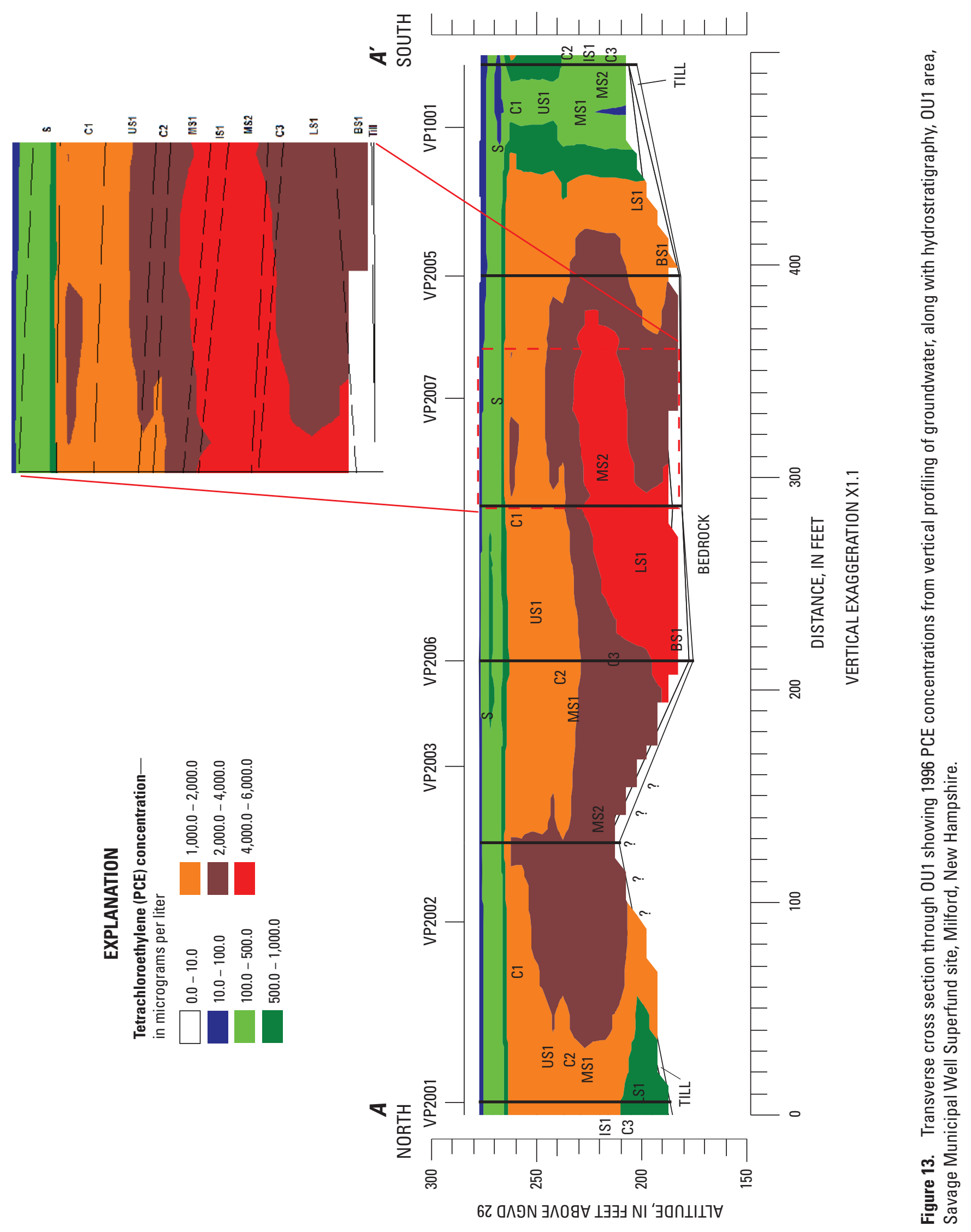



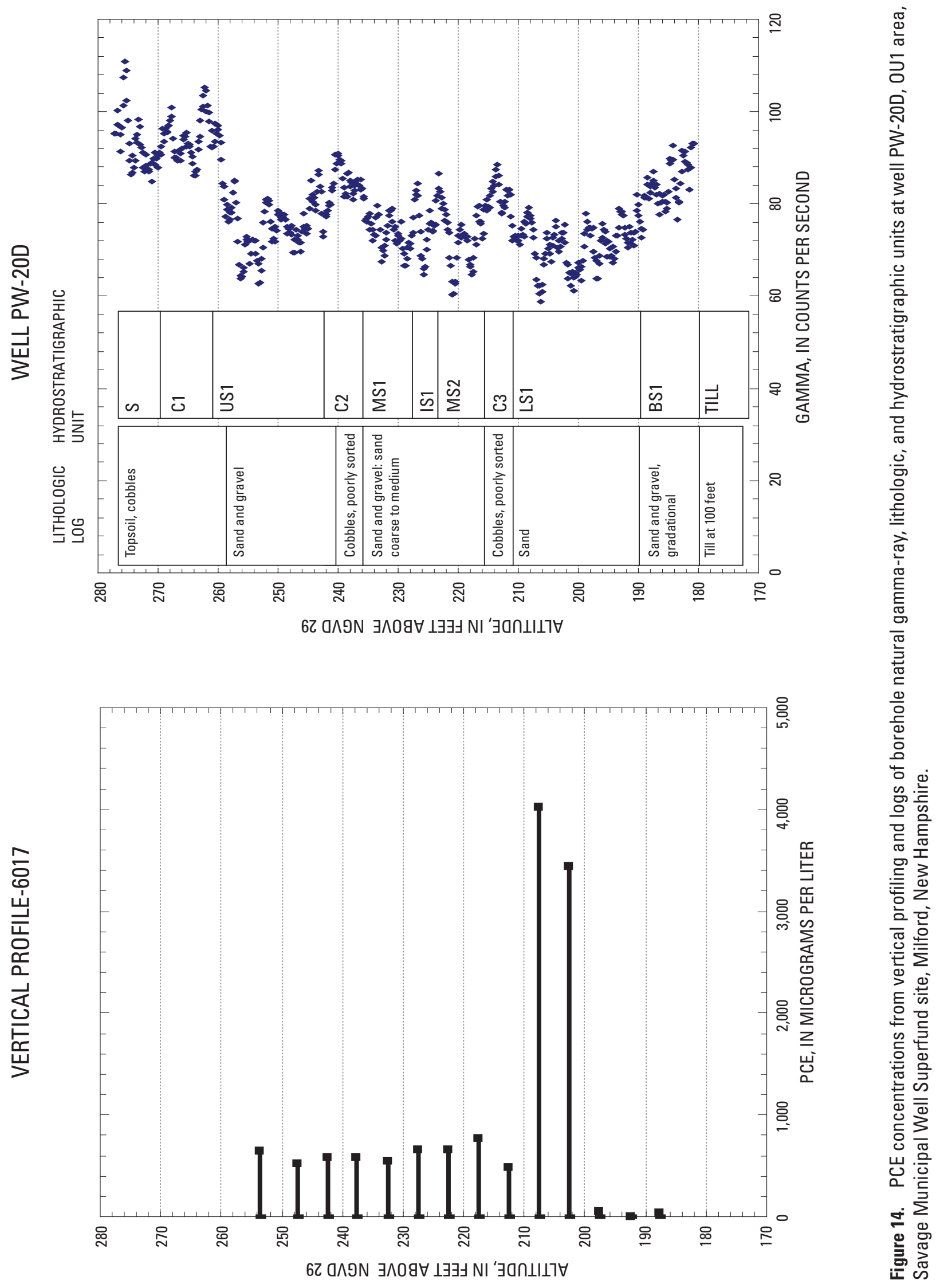


\section{Summary and Conclusions}

The hydrostratigraphy of the Operable Unit 1 (OU1) area of the Savage Municipal Well Superfund site and the underlying Milford-Souhegan Glacial Drift aquifer was mapped to establish a framework to understand solute transport of volatile organic compounds (primarily tetrachloroethylene (PCE)), assess spatial and temporal concentration patterns of PCE, and to provide a hydrostratigraphic framework that can be used by site managers to evaluate remedial efforts. The subsurface unconsolidated sediments (overburden) at OU1 are heterogeneous. Test drilling over the years by multiple drillers and variations in lithologic descriptions of sediments made it difficult to develop a framework for the site from these data. In the absence of high-resolution lithologic sampling and consistent descriptions, borehole geophysical logging (natural gamma-ray and electromagnetic logs) was used to characterize the subsurface geology.

A total of 11 primary hydrostratigraphic units in OU1 were mapped. These 11 units consist of several well-sorted sandy layers with some gravel that are separated by poorly sorted cobble layers with a fine-grained matrix. The cobble layers likely represent topset beds deposited in a glaciodeltaic environment within close proximity to the glacial ice front. The 11 hydrostratigraphic units are mostly semi-planar and truncated by an undulating, underlying bedrock surface. The lowermost overburden unit is a basal till that ranges in thickness from zero to greater than 10 feet and mantles the bedrock surface.

The 11 primary units have different lithologic and hydraulic characteristics. The hydraulic conductivity (nondirectional measurements) of the well-sorted sandy units typically is greater than that of the poorly sorted cobble units and the basal till. Hydraulic conductivity ranges over approximately two orders of magnitude from 5 to greater than 500 feet per day among the till and the sandy units. Lateral and vertical variations in lithology and hydraulic conductivity are evident from borehole natural gamma-ray counts and hydraulic conductivity measurements.

Comparison of hydrostratigraphic units with PCE concentrations suggests that solute transport away from source areas is primarily lateral within the permeable sandy units in the middle to lower parts of the aquifer. Comparison of high PCE concentrations (greater than 1,000 micrograms per liter $(\mu \mathrm{g} / \mathrm{L}))$ with borehole natural gamma-ray logs shows associations of high PCE concentrations with hydrostratigraphic units that are characterized by low gamma-ray counts and consist of permeable sandy units. These permeable deposits include a lower sand unit (LS1) and several overlying middle sand units (MS1 and MS2). Horizontal heterogeneity within the sandy units was inferred from borehole gamma-ray counts, which indicate the area near borehole PW-6R contains the most permeable deposits.

The location of the contaminant source can be traced based on the spatial distribution of high PCE concentrations.
Because high PCE concentrations were found within the permeable units and primarily near stratigraphic contacts, residual PCE sources are probably located at stratigraphic contacts between high and low permeability layers and (or) within the less permeable layers; if it is within the low permeability layers, the PCE would eventually vertically migrate into the more permeable layers and be transported within them. In the absence of residual high PCE concentrations or source zones, PCE concentrations in highly permeable layers would be lower than PCE concentrations in less permeable layers because flushing rates are faster in high permeability layers than in low permeability layers.

For successful remediation inside the barrier wall, high residual PCE source areas would need to be targeted for clean up, which would reduce transport of PCE to downgradient areas. Once this was achieved, conventional pump-and-treat remediation may initially prove effective in reducing PCE concentrations, given that solute transport occurs primarily in the permeable, middle to lower sandy (MS1, MS2, and LS1) units. Eventually, the rate of vertical transport of PCE through the cobble units $(\mathrm{C} 1, \mathrm{C} 2$, and $\mathrm{C} 3)$ and the interbedded sand and gravel unit (IS1) may limit the effectiveness of the remediation after the permeable units are remediated.

\section{Selected References}

Alyamani, M.S., and Sen, Zekai, 1993, Determination of hydraulic conductivity from complete grain-size distribution curves: Ground Water, v. 31, no. 4, p. 551-555.

Brayton, M.J., and Harte, P.T., 2001, Results of a monitoring program of continuous water levels, specific conductance, and water temperature at the OK Tool facility of the Savage Municipal Well Superfund site, Milford, New Hampshire: U.S. Geological Survey Open-File Report 01-338, 50 p.

Camp, Dresser, and McKee, Inc., 1996, Conceptual remedial design report for OK tool source area, Savage Municipal Supply Well, Superfund site-OU1, Milford, New Hampshire: Cambridge, Mass., March 1996, v. 1, 5 chaps., variously paginated.

Camp, Dresser, and McKee, Inc., 2001, Summary of investigations Re: Draining of bulk solvent storage tank, OK Tool/Savage Municipal Supply Well, Milford, New Hampshire: Cambridge, Mass., November 2001, variously paginated.

Camp, Dresser, and McKee, Inc., Federal Programs Corporation, 1995, Final report of vertical contaminant profiling, Savage Municipal Supply Well, Superfund site-OU1, Milford, New Hampshire: Boston, Mass., November 1995, 5 chaps., 5 apps.

Freeze, R.A., and Cherry, J.A., 1979, Groundwater: Englewood, N.J., Prentice Hall, Inc., 604 p. 
Guilbeaut, M.A., 1999, Suspended DNAPL source zones in three sandy aquifers: Plume anatomy, mass discharge, and sampling scale considerations: Waterloo, Ontario, University of Waterloo, Department of Earth Sciences, Master's thesis, $154 \mathrm{p}$.

Guilbeaut, M.A., Cherry, J.A., and Parker, B.L., 1997, Final report, Groundwater and soil sampling at the Savage Well Superfund site, Milford, New Hampshire: Waterloo, Ontario, University of Waterloo, Department of Earth Sciences, variously paginated.

Guilbeaut, M.A., Cherry, J.A., and Parker, B.L., 1998, Phase 2, Groundwater and soil sampling at the Savage Well Superfund site, Milford, New Hampshire: Waterloo, Ontario, University of Waterloo, Department of Earth Sciences, variously paginated.

Guilbeault, M.A., Parker, B.L., and Cherry, J.A., 2005, Mass and flux distributions from DNAPL zones in sandy aquifers: Ground Water, v. 43, no. 1, p. 70-86.

Halford, K.J., and Kuniansky, E.L., 2002, Documentation of spreadsheets for the analysis of aquifer-test and slug-test data: U.S. Geological Survey Open-File Report 2002-197, $51 \mathrm{p}$.

Harding ESE, Inc., 2002, Draft 2001 field investigation report Savage Well Superfund site, Milford, New Hampshire: Merrimack, N.H., July 9, 2002, variously paginated.

Harte, P.T., 2004, Simulation of solute transport of tetrachloroethylene in ground water of the glacial-drift aquifer at the Savage Municipal Well Superfund site, Milford, New Hampshire, 1960-2000: U.S. Geological Survey Scientific Investigations Report 2004-5176, 84 p.

Harte, P.T., 2005, Results of a monitoring program of continuous water levels and physical water properties at the OU1 area of the Savage Municipal Well Superfund site, water years 2000-03, Milford, New Hampshire: U.S. Geological Survey Open-File Report 2005-1303, 44 p.

Harte, P.T., 2006, Effects of a remedial system and its operation on volatile organic compound-contaminated ground water, Operable Unit 1, Savage Municipal Well Superfund site, Milford, New Hampshire, 1998-2004: U.S. Geological Survey Scientific Investigations Report 2006-5083, 87 p.

Harte, P.T., 2008, Differential rates of PCE declines in a sand and gravel aquifer, in Proceedings of National Ground Water Association 2008 Ground Water Summit, Memphis, Tenn., 1 p.
Harte, P.T., Andrews, T.C., and Spina, Paul, 2002, Use of passive-diffusion bag samplers to estimate vertical distribution of DNAPL's, in Proceedings of National Ground Water Association, Eastern Region Focus Conference, October 2002, Burlington, Vt., 1 p.

Harte, P.T., Brayton, M.J., Ives, Wayne, Perkins, Sharon, and Brown, Carroll, 2001, Testing and application of waterdiffusion samplers to identify temporal trends in volatileorganic compounds: U.S. Geological Survey Open-File Report 00-196, 91 p.

Harte, P.T., Flynn, R.J., Kiah, R.G., Severance, Timothy, and Coakley, M.F., 1997, Information on hydrologic and physical properties of water to assess transient hydrology of the Milford-Souhegan Glacial-Drift aquifer, Milford, New Hampshire: U.S. Geological Survey Open-File Report 97-414, 96 p.

Harte, P.T., Flynn, R.J., and Mack, T.J., 1999, Construction and calibration of numerical ground-water flow models of the Milford-Souhegan Glacial Drift aquifer, Milford, New Hampshire: U.S. Geological Survey Open-File Report 99-462, 76 p.

Harte, P.T., and Mack, T.J., 1992, Geohydrology of, and simulation of, ground-water flow in the Milford-Souhegan Glacial-Drift aquifer, Milford, New Hampshire:

U.S. Geological Survey Water-Resources Investigations Report 91-4177, 90 p.

Harte, P.T., and Willey, R.E., 1997, Effects of historical withdrawals on advective transport of contaminated ground waters in a glacial-drift aquifer, Milford, New Hampshire: U.S. Geological Survey Fact Sheet 162-97, 6 p.

HMM Associates, Inc., 1989, Draft remedial investigation, Savage well site, Milford, New Hampshire: Concord, Mass., no. 2176 HAZ/2880, 218 p.

HMM Associates, Inc., 1991, Remedial investigation, Savage well site, Milford, New Hampshire: Concord, Mass., no. $2176 \mathrm{HAZ} / 4814,800$ p.

Keys, S.W., 1990, Borehole geophysics applied to groundwater investigations: U.S. Geological Survey Techniques of Water-Resources Investigations, book 2, chap. E2, p. 150.

Kostic, B., Becht, A., and Aigner, T., 2005, 3-D sedimentary architecture of a Quaternary gravel delta (SW-Germany): Implications for hydrostratigraphy: Sedimentary Geology, no. 181 , p. $147-171$.

Koteff, Carl, 1970, Surficial geologic map of the Milford quadrangle, Hillsborough County, New Hampshire: U.S. Geological Survey Geologic Quadrangle Map GQ-881, scale 1:62,500. 
Krumbein, W.C., and Monk, G.D., 1942, Permeability as a function of the size parameters of unconsolidated sand: Trans American Institute Mining Metallurgical Engineers, v. 151, p. $153-163$.

Lyons, J.B., Bothner, W.A., Moench, R.H., and Thompson, J.B., 1997, Bedrock geologic map of New Hampshire: U.S. Geological Survey State Geologic Map, 2 sheets, scale 1:250,000 and 1:500,000.

Mount Sopris Instruments, Inc., 2002, 2PIA-100 Poly Induction Probe Manual: Golden, Colo., Mount Sopris Instruments Co., Inc., 19 p.

N.A. Water Systems, 2003, Annual report of the groundwater remediation progress at the Savage Municipal Water Supply Well Superfund site, OU-1, the OK Tool site July 2002 June 2003: Moon Township, Pa., N.A. Water Systems, Inc., variously paginated.

N.A. Water Systems, 2005, Report on vertical profiling at the Savage Municipal Water Supply Well Superfund site, OU-1, The OK Tool Site: Moon Township, Pa., N.A. Water Systems, Inc., variously paginated.

N.A. Water Systems, 2006a, Annual report of the groundwater remediation progress at the Savage Municipal Water Supply Well Superfund site, OU-1, the OK Tool site July 2005June 2006: Moon Township, Pa., N.A. Water Systems, Inc., variously paginated.

N.A. Water Systems, 2006b, In-Situ Chemical OxidationPhase II Program at the OK Tool source area Savage Municipal Well Superfund site Draft Copy: Moon Township, Pa., N.A. Water Systems, Inc., variously paginated.

N.A. Water Systems, 2007, Annual report of the groundwater remediation progress at the Savage Municipal Water Supply Well Superfund site, OU-1, the OK Tool site July 2006June 2007: Moon Township, Pa., N.A. Water Systems, Inc., variously paginated.

New Hampshire Department of Environmental Services, 2003, First five-year review report for Savage Well Municipal Supply Superfund site, OU-1 Milford, Hillsborough County, New Hampshire: Concord, N.H., variously paginated.

Olney, S.L., 1983, An investigation of the relationship between the coefficient of permeability and effective grain size of unconsolidated sand: Boston, Mass., Boston University, unpublished Master's thesis, $61 \mathrm{p}$.
Porges, R.E., and Hammer, M.J., 2007, The compendium of hydrogeology: Dublin, Ohio, National Ground Water Association, $303 \mathrm{p}$.

QST Environmental, Inc., 1997, Draft remedial design investigation report: Nashua, N.H., variously paginated.

Randall, A.D., 2001, Hydrogeologic framework of stratifieddrift aquifers in the glaciated northeastern United StatesRegional Aquifer System Analysis - northeastern United States: U.S. Geological Survey Professional Paper 1415-B, 179 p.

Tetra Tech EM, Inc., 2003, U.S. Environmental Protection Agency and Idaho National Engineering and Environmental Laboratory, 2003, Superfund innovative technology evaluation site program summary report:

U.S. Environmental Protection Agency Region 1, Contract no. 68-C5-0037, variously paginated.

U.S. Environmental Protection Agency, 1999, Use of monitored natural attenuation at Superfund, RCRA corrective action, and underground storage tank sites: Washington, D.C., Publication no. 540/R-99/009, 39 p.

U.S. Environmental Protection Agency, 2000, National water quality inventory-1998 Report: Washington D.C., Report no. EPA-841-F-00-006, variously paginated.

U.S. Environmental Protection Agency, 2001, Draft, Remedial systems evaluation, Savage Municipal Water Supply Superfund site, Milford, New Hampshire: Edison, N.J., U.S. Environmental Protection Agency Technology Innovation Office, $27 \mathrm{p}$.

U.S. Filter, Inc., 2004, Annual report of the groundwater remediation progress at the Savage Municipal Water Supply Superfund site, OU-1, The OK Tool site, July 2002 through June 2003: State College, Pa., U.S. Filter Engineering and Construction, variously paginated.

Wentworth, C.K., 1922, A scale of grade and class terms for clastic sediments: Journal of Geology, no. 30, p. 377-392.

Williams, J., and Lane, J.W., Jr., 1998, Advances in borehole geophysics for ground-water investigations: U.S. Geological Survey Fact Sheet 002-98, 6 p.

Zheng, Chunmiao, and Bennett, G.D., 1995, Applied contaminant transport modeling: New York, Van Nostrand Reinhold, 440 p. 


\section{Appendix 1}

Estimates of hydraulic conductivity were made using various grain-size methods (table 1-1). The method developed by Alaymani and Sen (1993) produced the lowest estimates on average, whereas the method of Olney (1983), utilizing the 75 percent effective grain size (D75, 75 percent of grains coarser), produced the highest estimates on average. The D75 method produced values 1.5 to 30 times that of the D90 method (90 percent of grains coarser) used by Olney (1983). The median values show that estimates made with the Krumbein and Monk (1942) method were consistently the highest (table 1-1). Four estimates were made with the Alaymani and Sen (1993) method to provide additional comparisons.

Estimates of hydraulic conductivity (non-directional) from three grain-size methods (excluding Olney D75) were compared to estimates of hydraulic conductivity from hydraulic tests (individual, single well test) reported for the B95 series wells by Camp, Dresser, and McKee, Inc. (1996) (table 1-2). The grain-size data were obtained from a 2-ft interval from one sample collected within the $10-\mathrm{ft}$ screen interval of each well. Therefore, the sample represents only 20 percent of the screen material. Nevertheless, the comparison is useful to gage the reliability of the grainsize methods because the hydraulic test is considered to incorporate a larger sample volume around the well screen.

Estimates of hydraulic conductivity made using the method developed by Krumbein and Monk (1942) were higher than estimates of hydraulic conductivity from hydraulic tests in four of five values. In contrast, the estimates made using the methods developed by Olney (1983) for D90 and Alaymani and Sen (1993) were higher than estimates from the hydraulic tests for two of the five wells. The comparisons indicate that the Olney D90 method provides reasonable estimates of hydraulic conductivity for the site, considering differences among the sample volumes from hydraulic tests and the three grain-size methods. Mack and Harte (1996) found similar differences among estimated values of hydraulic conductivity made using multiple methods. 
Table 1-1. Comparison of grain-size-analysis methods from lithologic samples in the OU1 area, Savage Superfund site, Milford, New Hampshire.

[D90 = 90 percent of grain size is coarser; D75 = 75 percent of grain size is coarser; PS = poorly sorted; MWS = medium-well sorted; VPS = very poorly sorted; --, no estimate made; hydraulic conductivity is non-directional]

\begin{tabular}{|c|c|c|c|c|c|c|c|}
\hline \multirow{3}{*}{ Well name } & \multirow{3}{*}{ Sample name } & \multirow{3}{*}{$\begin{array}{l}\text { Sample depth below } \\
\text { land surface, } \\
\text { in feet }\end{array}$} & \multicolumn{5}{|c|}{$\begin{array}{l}\text { Hydraulic conductivity, } \\
\text { in feet per day }\end{array}$} \\
\hline & & & \multicolumn{3}{|c|}{$\begin{array}{l}\text { OIney } \\
\text { (1983) }\end{array}$} & \multirow{2}{*}{$\begin{array}{l}\text { Krumbein } \\
\text { and Monk } \\
(1942)\end{array}$} & \multirow{2}{*}{$\begin{array}{c}\text { Alymani } \\
\text { and Sen } \\
\text { (1993) }\end{array}$} \\
\hline & & & D90 & D75 & $\begin{array}{c}\text { Sorting characteristic } \\
\text { of sample }\end{array}$ & & \\
\hline PW-21 & S-4B & 61.9 & 196 & 4,644 & PS & 5,153 & -- \\
\hline PW-21 & S-3B & 61.9 & 76 & 1,246 & PS & 2,620 & -- \\
\hline PW-21 & S-3 & 60 & 1,479 & 47,733 & MWS & 15,526 & -- \\
\hline PW-20M & S-8 & 71 & 6 & 8 & PS & 22 & 8 \\
\hline PW-6MB & S-4B & 63 & 17 & 66 & PS & 115 & 5 \\
\hline PW-6MB & S-4A & 63 & 11 & 45 & PS & 67 & 6 \\
\hline PW-6MB & S-5 & 64 & 8 & 49 & PS & 79 & -- \\
\hline PW-20M & S-4 & 40 & 10 & 69 & PS & 124 & -- \\
\hline PW-20M & S-5 & 47 & 16 & 45 & PS & 60 & -- \\
\hline \multirow{5}{*}{ PW-15M } & Median & & 13.5 & 57.5 & & 83.0 & 5.5 \\
\hline & Number o & samples & 12 & 12 & & 12 & 4 \\
\hline & Standard & eviation & 420.6 & $13,679.6$ & & $4,541.9$ & 2.4 \\
\hline & Maximum & & $1,479.0$ & $47,733.0$ & & $15,526.0$ & 8.3 \\
\hline & Minimum & & 5.0 & 7.0 & & 22.0 & 2.7 \\
\hline
\end{tabular}


Table 1-2. Comparison of hydraulic conductivities between hydraulic tests of single wells and grain-size analyses, OU1 area, Savage Superfund site, Milford, New Hampshire.

[Yellow shading indicates grain-size estimate of hydraulic conductivity closest value to single well test; --, no data; hydraulic conductivity is non-directional]

\begin{tabular}{|c|c|c|c|c|c|c|c|c|}
\hline \multirow{2}{*}{$\begin{array}{c}\text { Well } \\
\text { name }\end{array}$} & \multirow{2}{*}{$\begin{array}{c}\text { Screen } \\
\text { interval, } \\
\text { in feet below } \\
\text { land surface }\end{array}$} & \multirow{2}{*}{$\begin{array}{l}\text { Grain-size } \\
\text { sample } \\
\text { interval, } \\
\text { in feet below } \\
\text { land surface }\end{array}$} & \multirow{2}{*}{$\begin{array}{l}\text { Estimates of hydraulic } \\
\text { conductivity from } \\
\text { single well test as } \\
\text { reported by CDM, Inc. } \\
\text { (1996) }\end{array}$} & \multicolumn{3}{|c|}{$\begin{array}{l}\text { Hydraulic conductivity from methods of } \\
\text { grain-size analysis, } \\
\text { in feet per day }\end{array}$} & \multicolumn{2}{|c|}{$\begin{array}{c}\text { Hydrostratigraphic } \\
\text { unit }\end{array}$} \\
\hline & & & & $\begin{array}{c}\text { Krumbien } \\
\text { and Monk } \\
\quad(1942)\end{array}$ & $\begin{array}{l}\text { Olney (1983)-D90 } \\
\text { (uses } 90 \text { percent } \\
\text { greater than as } \\
\text { effective grain size) }\end{array}$ & $\begin{array}{l}\text { Alyamani } \\
\text { and Sen } \\
(1993)\end{array}$ & $\begin{array}{l}\text { Grain- } \\
\text { size } \\
\text { interval }\end{array}$ & $\begin{array}{l}\text { Screen } \\
\text { interval }\end{array}$ \\
\hline B95-5 & $37-47$ & $43-45$ & 168 & 712 & 595 & 91 & -- & -- \\
\hline B95-7 & $46-56$ & $49-51$ & 37 & 309 & 13 & 99 & -- & -- \\
\hline
\end{tabular}




\section{References}

Alyamani, M.S., and Zen, Zekai, 1993, Determination of hydraulic conductivity from complete grain-size distribution curves: Ground Water, v. 31, no. 4, p. 551-555.

Camp, Dresser, and McKee, Inc., 1996, Conceptual remedial design report for OK tool source area, Savage Municipal Supply Well, Superfund site-OU1, Milford, New Hampshire: Cambridge, Mass., March 1996, v. 1, 5 chaps., variously paginated.

Chen, X.H., 2000, Measurement of streambed hydraulic conductivity and its anisotropy: Environmental Geology, v. 39 , no. 12 , p. 1317-1324.

Krumbein, W.C., and Monk, G.D., 1942, Permeability as a function of the size parameters of unconsolidated sand: Trans American Institute Mining Metallurgical Engineers, v. 151, p. $153-163$.

Mack, T.J., and Harte, P.T., 1996, Analysis of aquifer tests to determine hydrologic and water-quality conditions in stratified-drift and riverbed sediments near a former municipal well, Milford, New Hampshire: U.S. Geological Survey Water-Resources Investigations Report 96-4019, $77 \mathrm{p}$.

Olney, S.L., 1983, An investigation of the relationship between the coefficient of permeability and effective grain size of unconsolidated sand: Boston, Mass., Boston University, unpublished Master's thesis, $61 \mathrm{p}$. 
Prepared by the Pembroke Publishing Service Center.

For more information concerning this report, contact:

Director

U.S. Geological Survey

New Hampshire-Vermont Water Science Center

331 Commerce Way, Suite 2

Pembroke, NH 03275

dc_nh@usgs.gov

or visit our Web site at:

http://nh.water.usgs.gov 

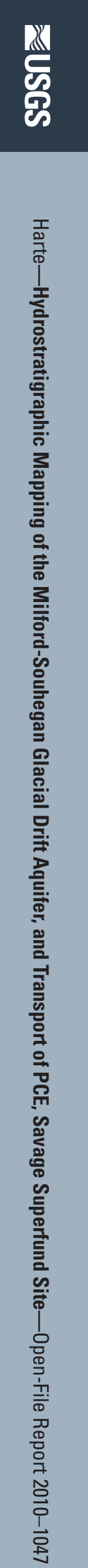